\title{
Varnhagen em movimento: breve antologia de uma existência
}

\author{
Temístocles Cezar
}

\begin{abstract}
Senhor! me dirigi a Paris a tratar da publicação da Historia Geral. Parei o tempo necessário para me entender com os artistas, e de novo serviu de muito a intervenção do benemerito do Brazil Ferdinand Denis. Estando em França não pude resistir, por differença de horas, à tentação de visitar a Hollanda, e cada vez bendigo mais o momento em que tal tentação tive. Não posso explicar a V. M. quanto ahi adquirí, assim nos archivos, guiado pelo Dr. Silva, como nos livreiros em folhetos antigos sobre o Brazil, cartas geographicas, conhecimento mais individual dos chefes hollandezes de Pernambuco, etc. Varias seç̧ôes da Historia geral darão disso prova manifesta. Na Hollanda não deixei de parar em Rotterdam, Amsterdam, Leyde, Delft, Utrecht, campo de Zeist (onde estive com o Sr. Netscher), Harlem e Nimégue. Devendo voltar da Hollanda a Barcelona, para não retroceder quasi pelo mesmo caminho, tinha sempre que fazer volta. Resolvi dal-a, ainda em favor da obra que está quasi a passar ao dominio publico, - quiz ir a Dresde consultar o célebre folheto Zeitung ausz Presillg Landt, que cita Humboldt, e que eu depois de o estudar não duvido divergir da opinião deste sábio, e atribuil-o ao anno de 1508, como explicarei em uma nota. Passei antes pelo Hannover e Berlim, estive em Potsdam, fui a Praga e Vienna, subi o Danúbio, Ischel, Salzburgo, Munich, Constança, Schasshann, Guvich, Berne, Genebra, Lyon, Avignon, Montpellier, Perpignan e Barcelona. Tudo isto rapidamente, já se vê, e só à força de actividade, e de considerar o viajar e o tempo, uma espécie de obrigação.

Carta de Varnhagen a d. Pedro II, $1853^{1}$
\end{abstract}

Varnhagen é assim, está sempre em movimento. Ele caminha constantemente, de um país a outro, de um arquivo a outro. Quase não pára, é infatigável. Como o Michelet de Roland Barthes, é um andarilho. ${ }^{2}$ Ao viajar, ao transpor fronteiras, ele vê a história. Porém sempre com esse olhar distanciado de quem viveu praticamente toda a vida fora do seu país. Estar longe da nação e ter como meta contar sua história; estar longe da nação e ter de consolidar sua nacionalidade como brasileiro, eis o dilema da vida e obra varnhageniana. Relacionar essas duas dimensões é o meu objetivo. Relacionar, portanto, vida e obra, pois acredito que Varnhagen escre- 
ve sobre o Brasil não apenas com a documentação que encontra e com os livros que lê, mas também a partir de sua experiência pessoal, de suas escolhas e de suas frustrações. Minha intenção, no entanto, não é fazer um estudo de psicologia histórica, mas um ensaio de biografia intelectual, ou antes, uma breve antologia de sua existência. ${ }^{3}$

Esboçar um Varnhagen em movimento, ou seja, a síntese de seus incessantes deslocamentos, não me impediu de tentar realizar um movimento dentro da obra, um movimento em Varnhagen, arriscando-me no seu interior, ao custo paradoxal de, eventualmente, cometer excessos interpretativos ou de deixar-me levar por ela. ${ }^{4}$ Exercitar a prudência nesse movimento de leitura não é tarefa fácil. Em primeiro lugar, a própria noção de movimento, físico e intelectual, está presente na produção varnhageniana: "tudo aquilo que excita o movimento; diz ele citando Alexander de Humboldt, 'o criador da ciência das viagens'; seja erro, seja previsão vaga e instintiva, seja argumento racional, conduz a ampliar a esfera das idéias". ${ }^{5}$ Em segundo lugar, escutar Varnhagen, através de seus trabalhos e de sua copiosa correspondência, é ouvir um discurso que vem do passado racionalizado pelo autor; não há imprevidência nele, suas polêmicas, por vezes acrimoniosas, são restritas, na maior parte das vezes, à disputa acadêmica. E mesmo quando o controle sobre o verbo parece escapar-lhe, os ataques que profere revertem-se em defesa do seu caráter. Talvez não seja exagero dizer que boa parte do que sabemos sobre Varnhagen, a partir de seus escritos, é um pouco o que ele queria que nós soubéssemos a seu respeito. Ele preocupava-se com sua vida e com sua posteridade. Essa cautela, todavia, não apenas foi insuficiente para impedir que se criasse em torno dele uma imagem antipática, como, ao que tudo indica, reforçou-a. Contudo, apesar de sua personalidade pouco sedutora, ele consegue impor-se, tornar-se imprescindível, irrecusável. Mesmo para aqueles que não o apreciam (e não parece, nem ontem nem hoje, que sejam poucos) ele se converteu em uma figura incontornável para o entendimento da história da história no e do Brasil.

\section{Varnhagen é um colega}

Quem é, afinal, Varnhagen? Discípulo de Ranke, dos positivistas, dos metódicos? Seria um detalhe praticamente não haver referências a Ranke 
em seus trabalhos? Em que positivismo ou em que princípio metódico deveríamos enquadrá-lo? Comte e Monod também são autores ausentes em sua obra. ${ }^{6}$ Capistrano de Abreu, em 1878, não lamentava que Varnhagen "ignorasse ou desdenhasse o corpo de doutrinas creadoras que nos últimos annos se constituiram em sciencia sob o nome de sociologia"? E Gilberto Freyre não o considerava de "um simplismo infantil quando deixa(va) a pura pesquisa histórica, pela filosofia da história"?8 Por outro lado, ele também não participa inteiramente desse movimento epistemológico que se consolida no século XIX, tributário da filosofia da história de Voltaire, de recusa à erudição, definida principalmente por seu componente antiquário. ${ }^{9}$

Sem pretender situá-lo em uma difícil e duvidosa história das influências podemos, ao menos, afirmar que Varnhagen compartilha uma série de noçóes gerais e difusas da moderna historiografia oitocentista que surge um pouco por todos os lugares à revelia da identificação com uma corrente teórica determinada: ou seja, aquela do estabelecimento da verdade histórica por meio do trabalho nos arquivos, da busca de documentos originais, da objetividade narrativa e da imparcialidade do historiador. ${ }^{10}$ "A escola histórica a que pertencemos - declara no prefácio à Historia das luctas com os Hollandezes no Brazil - é, como já temos dito por vezes, estranha a essa demasiado sentimental, que, pretendendo comover muito, chega a afastar-se da própria verdade." ${ }^{11}$ Deste conjunto de prescriçôes, a mais decisiva para a epistemologia histórica do século XIX era, segundo Hannah Arendt, a questão da imparcialidade do historiador. ${ }^{12}$ E nela, apesar de seu esforço retórico, Varnhagen perde-se completamente. A distinção entre sujeito e objeto da pesquisa, fundamento teórico da emergente ciência histórica, era uma premissa que Varnhagen tinha muita dificuldade em respeitar. Ele a elidia com mais freqüência que supunha e que nós, à primeira vista, possamos supor. A presença do autor no interior de suas composiçóes é algo que impressiona. "Narraremos, explica no primeiro capítulo da Historia geral do Brazil, os successos segundo nol-os hajam apresentados, em vista dos documentos, a reflexão e o estudo; e alguma que outra vez, sem abusar, tomaremos a nosso cargo fazer aquellas ponderações a que formos levados por intimas convicções; pois triste do historiador que as não tem relativamente ao seu paiz, ou que tendo-as, 
não ousa apresental-as." ${ }^{13}$ Mesmo no seu trabalho mais ponderado, mais próximo do que a ciência da história do século XIX era capaz, ele não consegue se ocultar no texto. Nem ao menos procura dissimular sua presença. Nesse sentido, um leitor atento como Capistrano de Abreu já nos advertia: "é preciso definir o temperamento de Varnhagen para bem comprehender a sua História geral." ${ }^{14}$

Varnhagen era monarquista. Sim, sem dúvida. E à sua maneira, era também um patriota. Era católico, como nunca cansou de afirmar. A crença, entretanto, não o impedia de censurar implacavelmente os jesuítas e, sobretudo, a Inquisição. ${ }^{15}$ Egocêntrico e carreirista, embora anacrônicas em relação ao contexto, não são atribuições despropositadas. Ambicioso? Ele tinha até uma teoria explicativa para a ambição, dele e dos outros. ${ }^{16}$ Antiindianista e hobbesiano são adjetivos que, talvez, igualmente lhe caiam bem, embora mais do que partidário de Hobbes, ele fosse um crítico de Rousseau. ${ }^{17}$ Anti-romântico? No início da sua trajetória intelectual, com certeza, não. Suas relações com Alexandre Herculano e a colaboração com o Panorama são indicadores seguros. ${ }^{18}$ Depois, sua postura crítica em relação aos índios o afastou desta versão brasileira do romantismo. Apesar disso, ele parece guardar preceitos da atmosfera romântica, desde, por exemplo, a busca pelo original e pelo nacional até a paixão pelas viagens. Ele é isto e aquilo, às vezes um pouco menos, às vezes um pouco mais. Ele é um colega, e acima de tudo é autor de uma obra imensa, que, embora a partir de um certo momento privilegie a história, atravessa vários domínios, da literatura à crítica literária, passando pela biografia, pela etnologia, pela política e diplomacia, pela economia e mesmo pela filologia. Vários campos de saber escritos (em diversos idiomas), todos aproximadamente da mesma maneira: sem estilo, sem elegância, em suma, uma linguagem nada aprimorada. É quase um consenso que Varnhagen não é um bom escritor. Nem de história, nem de gênero algum. Ele vive, nesse caso, o dilema oposto ao de Michelet, que foi acusado de ser um mau historiador porque escrevia, no lugar de simplesmente redigir. ${ }^{19}$ Já Varnhagen não escrevia, redigia. Essa crítica, acredito, decorre antes de uma importante aporia da cultura histórica do século XIX e início do século XX, cuja origem talvez remonte ao princípio aristotélico da superioridade da poesia em relação à história, do que propriamente de uma 
orientação teórica de como ela devia ser escrita. ${ }^{20}$ Assim, do mesmo modo que o Instituto Histórico e Geográfico Brasileiro (IHGB), freqüentado por literatos em profusão, é um palco onde se manifestam as indefinições entre a moderna narrativa, científica, neutra e objetiva, e a narrativa literária, sujeita sempre às injunçôes da subjetividade do autor, também nas obras de Oliveira Lima e Tristão de Araripe, ou mesmo de Capistrano de Abreu, ou ainda de José Veríssimo, que por mais que tentem sair dele ainda respiram no mesmo regime de historicidade de Varnhagen, a questão não está definida e o bom e velho estilo ainda é um atributo importante. ${ }^{21}$

Além disso, como o Michelet de Charles Péguy, Varnhagen é um historiador solitário. Ele não compartilha seu trabalho com ninguém. ${ }^{22}$ Ele se encerra nos arquivos onde compulsa, colige, copia e deixa sua marca. ${ }^{23}$ Em seguida ele ordena o material, divulga e publica o que bem entende, mas não sem antes fazer uma apreciação teórica, isto é, "unil-os e combinal-os em doutrinas que façam tal ou tal corpo". ${ }^{24}$ Embora houvesse no IHGB uma exortação ao trabalho em equipe desde a sua fundação, na prática a pesquisa individual preponderava. ${ }^{25} \mathrm{O}$ isolamento de Varnhagen em relação a seus pares, logo, não seria um traço específico de sua personalidade intelectual, não fosse pelo fato de podermos relacioná-lo a uma certa necessidade que tem de ser o primeiro, o iniciador, aquele a quem se deve o começo. $\mathrm{O}$ epíteto de Heródoto brasileiro não lhe será atribuído pela historiografia moderna ao acaso. Não parece uma mera coincidência que Robert Southey, que tinha a pretensão de que sua obra significasse para os brasileiros o que a de Heródoto representava para os europeus, tenha sido duramente criticado por Varnhagen. ${ }^{26}$ History of Brazil, publicada em três volumes nos anos 1810, seria, segundo o comentário que se encontra na primeira edição da Historia geral do Brazil, de 1854, sem unidade, desordenada, repetitiva e fatigante, características responsáveis pela sua frágil recepção (a ausência, naquele momento, de uma tradução para o português é simplesmente desconsiderada pelo brasileiro). É compreensível, pois Southey antes de ser um bom historiador era, conforme uma precisão nada desinteressada de Varnhagen, um "illustre poeta laureado". ${ }^{27} \mathrm{~A}$ obra do inglês poderia, no máximo, aspirar à condição de memória para escrever a história do Brasil e dos países do Prata. ${ }^{28}$ Quase uma fonte, portanto. Quem sabe por essa razão ele tivesse tanta dificuldade de se distan- 
ciar dela. Ao que tudo indica, a primeira história do Brasil deveria ser a dele, e o primeiro historiador brasileiro deveria ser ele. Não que Varnhagen pensasse isso desde o começo de sua carreira. A Historia geral inclusive foi projetada inicialmente como uma Geographia Physica do Brazil. ${ }^{29} \mathrm{~A}$ tentação herodotiana foi tomando forma aos poucos, à medida que suas pesquisas desenvolviam-se de forma cada vez mais profissional, conforme, enfim, o ritmo de seus movimentos, cujos passos tento perseguir.

Porto Seguro: início e fim

Meus trabalhos sobre a história de meu país, eu confesso aqui sem muita presunção, não são totalmente desconhecidos na Europa; e ouso mesmo a acreditar que esses estudos sérios serviram de alguma maneira para o título que hoje detenho graças à benevolência de meu soberano. Todo mundo sabe que Porto Seguro, no sul da Bahia, indica o local, para sempre memorável, onde o Brasil foi descoberto por Cabral, e que essa descoberta marca o ponto de partida da civilização do vasto império brasileiro. (Varnhagen) ${ }^{30}$

Comecemos pelo fim, ou melhor, por um determinado início. Porto Seguro. Local onde a esquadra de Cabral desembarcou em abril de 1500. O mesmo Cabral, cujo túmulo veio a ser descoberto, no final dos anos 1830, pelo jovem Varnhagen no Convento da Graça em Santarém, Portugal. Descobrir aquele que uma certa historiografia chama de o "descobridor”, embora dela o historiador não participe, não deve ter feito mal para quem logo se tornará um perseguidor infatigável da origem nacional. Para ele, é a Vasco da Gama que se deve "verdadeiramente o feliz achamento do Brazil", achado este inexorável posto que não fosse essa "primeira expedição que o seguiu, não poderia deixar de ter logar n'um dos annos immediatos". A associação do nome de Cabral ao descobrimento do Brasil não encontra, para Varnhagen, amparo na "boa crítica" que "não lhe reconhece maior serviço do que o do feliz alviçareiro que anuncia na praça o apparecimento de um navio à barra”. ${ }^{31} \mathrm{Na}$ segunda edição da Historia geral, em 1877, Vasco da Gama continua sendo o responsável pelo descobrimento, entretanto essa última passagem foi suprimida. ${ }^{32}$ Os títulos de nobreza outorgados a ele nesse período teriam alguma relação com o abandono da "boa crítica"? 
Barão de Porto Seguro em 1872, depois, em 1874, visconde de Porto Seguro. Varnhagen, aos 56 anos de idade, não esperava mais, caso se confie em suas palavras, uma tal distinção de parte do imperador. Viajante compulsivo, ao receber o título de barão ele não se encontrava no Brasil, nem mesmo em Viena, onde ocupava o posto de ministro Plenipotenciário do governo brasileiro no Império austro-húngaro. Ele participa, em São Petersburgo, de um congresso de estatística. Das águas geladas do Neva, escreve a d. Pedro II, agradecendo-lhe não apenas o gesto que o nobilitou, mas também o "bello nome" que o imperador lhe havia atribuído:

Ainda que muitas vezes me incommodei vendo-me considerado aos olhos da Europa, e especialmente da Allemanha, em virtude do meu appelido, como menos brazileiro não pensava já agora separar-me, sem saudade nem extranheza, desse nome, que durante perto de quarenta annos procurei illustrar e honrar, illustrando-me e honrando-me; e confesso a V. M. I. que já não tinha esperança, nem aspiração, de o ver trocado por outro... Porém o mágico nome de Porto Seguro, tão querido para quem tinha levado esses quarenta annos sempre occupado da região de Cabral, operou o prodigio, e até me obrigou a mais, na minha $2^{2}$ edição da Historia Geral..$^{33}$

Durante esses quarenta anos, até sua morte, em Viena em 1878, o visconde de Porto Seguro teve de suportar certas dúvidas e ironias acerca de sua lealdade à nação. Francisco Adolfo de Varnhagen nasceu, segundo seu certificado de batismo, em 17 de fevereiro de 1816, em Sorocaba, na província de São Paulo. ${ }^{34}$ Não obstante, a nacionalidade daquele que se torna o historiador por excelência do Império teve de lhe ser outorgada.

\section{Nacionalidade, esquecimento, abnegação}

Na primeira audiencia que tive destes Augustos Senhores conheci que se surprehendiam de não me achar estrangeiro ou ao menos estrangeirado, $\mathrm{e}$ que eu não correspondia pessoalmente à idéa que, pelo meu nome, haviam anteriormente formado, imaginando-me hollandez, segundo creio. - Confesso que por esta occasião se me justificou uma apprehensão que sepultava no fundo d'alma e que não contava revelar a ninguém por escripto; mas que agora me decido a transmittir a V. M. I., de cuja circunspecção e reserva sou tão grande admirador. - Sabe agora V. M. I. uma das razóes por que eu queria omittir o meu nome na Historia geral do Brazil, deixando 
até de assignar a dedicatoria. Sem o meu nome a obra seria apenas de um brazileiro ou do Instituto H. do Brazil; e, por conseguinte, de todo o Brazil. (Carta de Varnhagen a d. Pedro II, 1854) ${ }^{35}$

Friedrich Ludwig Wilhelm de Varnhagen, militar e engenheiro de origem germânica, foi contratado, em 1802, pelo governo metropolitano para comandar, sob a direção do intendente José Bonifácio, fundições portuguesas pelo período de dez anos. Em 1806, casa-se com d. Maria Flávia de Sá Magalhães, de nacionalidade ainda não confirmada, provavelmente brasileira ou portuguesa. ${ }^{36}$ Francisco Adolfo de Varnhagen é o sétimo filho do casal. Transferido para o Brasil em 1809, Friedrich de Varnhagen veio com a missão, segundo contará mais tarde o historiador da família, de começar nada menos que a siderurgia nacional na Real Fabrica de Ferro de São João de Ipanema, em Sorocaba. Nela, Varnhagen passa os primeiros sete anos de sua vida. A fábrica ficava em um lugar conhecido. Remontava ao século XVI, e até o fim do século XVIII tinha passado por diversos problemas que muito prejudicaram seu bom funcionamento. ${ }^{37}$ Sua antiguidade e suas características particulares atraíram visitantes ilustres, políticos como o próprio José Bonifácio, homens de ciência como os mineralogistas Seiblitz, Eschwege e Feldner (estes dois últimos vieram com o pai de Varnhagen) e os viajantes naturalistas barão de Olfers, Sellow, von Natterer e Saint-Hilaire, entre outros. Alguns desses visitantes são convertidos em personagens de uma trama novelesca, cujo ator principal é seu pai, e que ocupa perto de um capítulo da Historia geral do Brazil.38

No ano da independência do Brasil, Friedrich de Varnhagen parte com uma licença ilimitada "à Europa, onde o chamavam outros interesses, e os justos desejos de ver seus pais, - de quem se havia separado vinte anos antes". ${ }^{39} \mathrm{O}$ restante da família fica no Rio de Janeiro, onde o jovem Varnhagen começa seus estudos de letras. Em outubro de 1823, Friedrich de Varnhagen chama-os a Portugal. Francisco Adolfo de Varnhagen nunca mais passará tanto tempo no Brasil.

No final de 1825, em Lisboa, Varnhagen ingressa no Real Colegio da Luz, onde durante sete anos obtém excelentes resultados em vários cursos, de acordo com seu próprio depoimento. Em 1832, ele estava, "se quisesse", apto a engajar-se no Exército português, que lhe oferecia certas 
vantagens: "honras de cadete com vencimento quase igual ao de Alferes". No entanto, ele "tinha só vistas de servir" no seu país, e se recusa a iniciar uma carreira em Portugal. Em julho de 1833, estando em férias, é surpreendido pela "restauração de Lisboa pelas armas do Immortal e Augusto Fundador do nosso Imperio" e "levado com muitos outros brasileiros pelo enthusiasmo de uma lucta tão justa contra um tyramno usurpador em pró de uma princeza e umas instituições emanadas do nosso solo, julguei dever empunhar as armas". A atitude quase irrefletida de Varnhagen é recompensada pelo governo português sem, faz questão de precisar, "preceder requerimento" de sua parte. Assim, em menos de três meses passa de "cadete alumno" a "Official de Artilharia". Nesse posto, participa do "resto da campanha a favor da causa Constitucional". A pressa com que Varnhagen tomou essa decisão revelou-se um grave erro: "achando-me assim, quase sem o pensar, engajado no serviço de um reino estranho, sem me haver lembrado de munir-me para isso da necessaria licença do nosso Governo, como manda a lei." Tal esquecimento tornou-se o problema mais difícil a ser superado no processo para reconhê-lo como brasileiro.

Durante o tempo em que esperava para poder reparar seu equívoco, resultado, segundo ele, de "um simples fanatismo da idade", Varnhagen segue seus estudos com aplicação: "fui ao Collegio dos Nobres habilitarme na lingua Allemã, e na Academia de Fortificação (depois convertida em Escola do Exercito) fui concluir o curso de Engenharia, o que fiz grangeando não só approvações plenas, mas mais uma vez o primeiro premio." Em razão disso, e de sua antiguidade, foi promovido ao posto de primeiro-tenente. Seu empenho intelectual também foi compensado com o convite para se associar à Academia Real das Sciencias de Lisboa, que publica a primeira "composição scientifico-litteraria" de Varnhagen, as "Reflexôes criticas", que lhe abrem igualmente as portas, em 1840, do IHGB. ${ }^{40}$ Uma recompensa decorrente de seus "desejos e patriotismo nunca arrefecido na ausencia da patria”.

No início de 1840, ao tomar conhecimento de que o Poder Legislativo estava discutindo uma lei que permitiria a repatriação de brasileiros que viviam no exterior, Varnhagen arruma as malas e parte para o Brasil. Enquanto aguarda a votação da lei, aproveita "o tempo para uma viagem ao interior do Imperio, a qual não só me prestou muitos conhecimentos 
naturaes, como de novo me arraigou sentimentos de patriotismo ao ver os meus lares e amigos de infancia”. ${ }^{41}$ Nessa viagem teve uma experiência que modificou completamente sua perspectiva em relação aos "selvagens", pelos quais, até aquele momento, nutria uma certa simpatia provocada, sobretudo, pela carta de Caminha. ${ }^{42}$ "A minha conversão, o meu horror pela selvageria nasceu em mim em meio dos nossos sertôes, e em presença, digamos assim, dessa mesma selvageria." Na companhia de tropeiros, fora ameaçado por índios "nada menos que na estrada real", explica na polêmica com João Francisco Lisboa. O episódio foi tão impressionante que

as illusões com que havia embalado o espirito no seio das grandes cidades se dissiparam n'um só dia; à maneira do que se passou com alguns politicos franceses ultra-philantropicos por theoria, durante toda a sua vida, e que tiveram que converter-se a idéas mais positivas e reaes, em presença dos horrores de Robespierre e de Marat, e em nossos dias das proprias scenas de $1848 .^{43}$

Após esse incidente, Varnhagen torna-se um crítico veemente do romantismo indigenista, ou do "perigoso brasileirismo caboclo", que dizia ao imperador não adular "servilmente, como outros". ${ }^{44}$

De retorno a Portugal, em 22 de junho de 1841, solicita ao governo de Portugal uma promoção, que lhe é recusada. Pelo menos para um de seus biógrafos, essa foi a principal causa do seu pedido de demissão do Exército português, ocorrido no dia $1^{\circ}$ de outubro de 1841 . De acordo com a hipótese de Clado Lessa, Varnhagen fizera uma solicitação que sabia não ter a menor chance de ser bem-sucedida. Ele estava com 25 anos, a maioridade civil à época, e era preciso resolver a questão da sua nacionalidade. Ainda segundo Lessa, ele não sabia que em 24 de setembro de 1841 , o Imperador havia assinado o decreto que confirmava a sua nacionalidade brasileira, anistiando-o, portanto, da irregularidade que cometera. Varnhagen somente teria tomado conhecimento da decisão em 19 de fevereiro de 1842. No entanto, na carta autobiográfica que enviou ao general Francisco Andréa, em 1843, ele omite o detalhe da solicitação de ascensão profissional ao governo português e da conseqüente resposta negativa. Ele afirma simplesmente que recebera a notícia do Brasil e que 
“desprezando todas as consideraçôes dictadas pela prudencia para não me sacrificar n'uma posição social vantajosa sem a certeza de outra, e entregue só à muita confiança, que sempre tive na munificência do nosso Imperador, dei a minha demissão do posto de 1o Tenente, no qual estava já pela escala o primeiro com direito a ser Capitão". ${ }^{45}$

Varnhagen, penso eu, tentava resolver sua vida, de um lado do Atlântico ou do outro. Em 1846, na polêmica que mantivera com José Ignacio de Abreu Lima, ele menciona, mais uma vez, essa passagem de uma maneira mais dramática e sem se preocupar muito em demonstrar qualquer traço de modéstia. Curiosamente, escreve sobre si na terceira pessoa: "rompendo por tudo; resignara os cargos que lhe offereciam uma brilhante carreira, segundo a opinião dos amigos, e até da corte, e se foi apresentar à nossa Legação em Lisboa como sudito brazileiro." ${ }^{46}$ Não é preciso insistir no evidente trabalho de valorização das disposiçôes afetivas em relação ao Brasil e do perfil de abnegado que Varnhagen procura delinear. Brasileiro por decreto, torna-se também historiador por um ato oficial. Em 19 de maio de 1842, é nomeado adido de primeira classe na Legação brasileira em Portugal, com a missão principal de pesquisar os documentos relativos à história, à geografia e à legislação do Brasil. ${ }^{47}$

\section{Um historiador-viajante}

Os archivos e bibliothecas da Europa, especialmente os de Portugal, contêm tão ricos e preciosos manuscriptos sobre o Imperio, que muito conviria ao Instituto tomar providencias, para os possuir por copia. Sobre este assumpto devia talvez intervir o governo, que devendo alimentar o espirito de nacionalidade, deve ter presente que são a primeira base talvez desta, a historia e o conhecimento do paiz natal. (Carta de Varnhagen a Januário da Cunha Barbosa, 1839) ${ }^{48}$

O tempo de manhã até às quatro horas está todo dividido entre a Legação (onde agora sirvo de secretário) e a Torre do Tombo, onde me vai aparecendo tanta coisa, que não devo fazer mais do que copiar e andar para diante. (Carta de Varnhagen a Januário da Cunha Barbosa, 1843) (99 $^{4}$

A diplomacia conferiu a Varnhagen as condições ideais para realizar seu trabalho de historiador: o tempo e as viagens. Pelo que pude verificar, domiciliado em Lisboa entre 1842 e 1847 , ele não sai da capital portu- 
guesa senão para ir a outros arquivos, como em Coimbra e Évora. No final de 1846, é encarregado de coletar documentos em Simancas, Madri e Sevilha, a fim de esclarecer questôes sobre as fronteiras brasileiras. Em 1847, promovido ao posto de primeiro-secretário da Legação brasileira, é transferido para Madri. Nos quatro anos seguintes, nada se passa nas relações diplomáticas que pudesse desviar a atenção do historiador dos arquivos. ${ }^{50}$ Ainda em 1847, o encontramos em uma missão de estudos em Paris e Londres, com o objetivo de analisar os manuscritos da obra de Gabriel Soares de Sousa que Ferdinand Denis e Robert Southey mencionam em seus trabalhos. No curso desse mesmo ano, visita outros países da Europa, sempre em busca de arquivos e fontes: vai à Bélgica, mais precisamente a Liège, Louvain, Bruxelas, Gand, Bruges e Ostende; à Alemanha, passando por Colônia, Bonn, Coblentze, Neuwied, Ehrenbreitstein, Mayence, Wiesbaden, Frankfurt, Heidelberg, Carlsruhe, Estrasburgo. Antes de voltar a Madri, passa por Cadiz, Sevilha, Córdoba, Granada, Gibraltar, Málaga e Castela. Demora-se um pouco mais em Toledo, Ávila, Valladolid, Valença, Burgos, Leão, Astorga, Tóro, Tordesilhas e Salamanca. Ele resiste à inércia. Por que parar se logo ali outro arquivo o espera? Se há, de fato, um ponto de contato entre Varnhagen e Ranke, como vários comentadores já salientaram mas poucos demonstraram efetivamente, esse me parece um dos mais evidentes: como Ranke, ele tem "o gosto pelo arquivo". ${ }^{51}$ Nesse agitado ano de 1847, o IHGB, na sessão realizada em 5 de agosto, concede a Varnhagen a medalha de ouro pelo seu trabalho sobre o Caramuru. Detalhe: na ata da sessão de 3 de julho consta a demanda do prêmio pelo próprio Varnhagen. ${ }^{52}$

Mas nem só de história vive o historiador. Em 1850, ele publica o Florilégio da poesia brazileira, cuja introdução, intitulada "Ensaio historico sobre as lettras no Brazil”, é considerada, por alguns estudiosos da literatura, como o texto fundador da "historiografia literária brasileira" ${ }^{53}$ O primeiro, mais uma vez o iniciador, apesar de existirem antologias anteriores à dele. Seja como for, o "Ensaio" e o Florilégio, a despeito de suas falhas, tornaram-se fontes de consulta constantes para os interessados na história literária brasileira já no século XIX, mesmo que muitos, segundo Capistrano de Abreu, não declarassem. ${ }^{54}$ Contudo, o mais espantoso nesse trabalho e na sua recepção é a capacidade que Varnhagen tem de 
decidir a respeito daquilo que é nacional e o que não é, assim como, por outro lado, ver seus ditados aceitos quase sem contestação. Nesse caso, a maior parte das críticas à obra são endereçadas aos julgamentos estéticos de Varnhagen e não à seleção que opera. Os critérios de representação dessas escolhas desaparecem sob o manto nacional com o qual Varnhagen as encobre.

Em abril de 1851, embarca para o Brasil em resposta a uma convocação do ministro Paulino José Soares de Sousa. O diplomata fora chamado na condição de expert em história e geografia: seu conhecimento era necessário para as negociações sobre os limites das repúblicas hispanoamericanas com as Guianas européias. Deixa Madri carregado: 916 páginas de documentos copiados em arquivos de Simancas, mapas, livros e manuscritos coligidos ao longo de suas investigaçôes. ${ }^{55}$ Durante sua estada na capital do Império, participa ativamente das sessões do IHGB, do qual é eleito primeiro-secretário em 23 de maio de 1851. Nessa função, reorganiza a biblioteca, os arquivos e o museu do instituto, e ainda estabelece o primeiro catálogo, por ordem alfabética, da Revista do IHGB até o número XV, consagrado ao ano de 1851. A gestão de Varnhagen coincide igualmente com a reforma dos estatutos e a tentativa de profissionalização da instituição. ${ }^{56}$

Antes de retornar a Madri, ainda em 1851, solicita sua demissão do posto de segundo-tenente do Imperial Corpo de Engenheiros do Exército brasileiro, cargo que lhe havia sido atribuído quando da nomeação à Legação em Lisboa. Mas não sem antes tentar uma promoção, que lhe foi, novamente, recusada. ${ }^{57}$ Em compensação, sua carreira diplomática e de historiador progrediam. Nesse mesmo ano, é elevado, em Madri, ao posto de Encarregado de Negócios, onde fica até 1858, momento em que uma nova promoção lhe é conferida: ministro residente no Paraguai. Aqui começa a etapa latino-americana de sua vida, que se estende por uma década.

\section{Os "tristes trópicos" de Varnhagen}

Ao partir para a América Latina, Varnhagen já havia publicado, entre 1854 e 1857, aquela que se tornou a sua principal obra: Historia geral do Brazil, a "massa cyclopica de materiais que acumulara", segundo Capis- 
trano de Abreu. ${ }^{58}$ Em conseqüência, em 1859, o IHGB elevou o historiador à categoria de sócio honorário, "em reconhecimento de sua ilustração e dos valiosos serviços prestados ao Instituto". ${ }^{59}$ Chegou ao Paraguai bem servido, portanto, de títulos diplomáticos e acadêmicos. Todavia, sua tolerância para com a república comandada por Carlos Antônio Lopes era escassa. Alegando problemas de saúde, Varnhagen, sem autorização oficial do governo imperial, deixa Assunção no final de 1860.

Por outro lado, enquanto o diplomata sente-se doente, o historiador parece saudável. Assim, durante sua viagem do Rio de Janeiro a Montevidéu, e desta à capital paraguaia, procura confirmar alguns detalhes do relato de Pero Lopes de Sousa de 1530 publicado por ele mesmo em 1839. ${ }^{60}$ Ele lamenta não poder seguir todo o itinerário do navegador português do século XVI, a fim de não somente confirmar e corrigir, mas também de redescobrir, de rever, aquilo que Pero Lopes de Sousa havia visto. $\mathrm{Na}$ mesma perspectiva de Heródoto ou dos românticos da primeira metade do século XIX, ele é um sujeito persuadido de que as viagens são instrumentos de saber.

Em janeiro de 1861, parte para a Venezuela para ocupar o posto de ministro residente do Brasil, responsável pelas relaçóes não apenas com aquele país, mas também com a Colômbia e o Equador. No transcurso da viagem que o conduz à nova missão, Varnhagen demora-se em diversos países antes de chegar a seu destino. É interessante seguir seu itinerário pari passu por alguns momentos. Como de hábito, a pesquisa é o seu passatempo. De Recife, ele envia, em 18 de abril, uma carta ao imperador contando, entre outras coisas, que "na Bahia fui a Caxoeira, e dahi por terra a Santo Amaro, e de S. Francisco por terra à Bahia, sempre com o Gabriel Soares na mão". ${ }^{61}$ A movimentação do Varnhagen etnólogo é continuamente acompanhada e dirigida pelas fontes históricas, sobretudo aquelas que são produto de suas próprias investigações. Ele tem também este perpétuo olhar sobre a história: Pero Lopes de Sousa e Gabriel Soares de Sousa funcionam, cem anos antes, como Jean de Léry para Lévi-Strauss: breviários que orientam a visão. ${ }^{62}$

De Recife, Varnhagen dirige-se ao Pará, na esperança de encontrar um barco que estivesse rumando para os Estados Unidos. 
Mallogrado, porém, na minha expectativa - narra a d. Pedro II -, voltei nelle mesmo com a vantagem de ter ficado conhecendo o proprio Pará, e por duas visitas (de ida e de volta) a Parahiba, Rio Grande, Ceará, Maranhão, além de grande parte da costa, junto à qual por aqui se navega. A $2^{\underline{a}}$ edição da minha Historia ganhará muito não só desta digressão de 15 dias, como das estadas aqui e na Bahia. ${ }^{63}$

De fato, na segunda edição da Historia geral, encontram-se diversos exemplos das anotaçóes tomadas durante essa viagem. Estas e outras notas são efeitos de uma prática silenciosa, pelo menos até o século XIX, através da qual os historiadores emprestam aos seus trabalhos garantias extratextuais: a autópsia, metodologia antiga, em que o olho funciona como "marca de enunciação, de um eu vi como intervenção do narrador em sua narrativa para provar" o que afirma. ${ }^{64}$ A passagem pela região pernambucana oferece a Varnhagen a chance de investigar certos lugares ocupados pelos holandeses no século XVII, experiência assinalada já no prefácio da sua Historia das luctas com os Hollandezes no Brazil, publicada em 1871:

Não pensávamos começar a redigir o livro projetado, sem examinar antes todos os pontos e percorrer todos os caminhos, onde, por seus patrióticos feitos, se imortalizaram os quatro herois brasileiros, anti-holandezes, Vidal, Barbalho, Camarão e Dias. ${ }^{65}$

As pesquisas no Nordeste brasileiro não foram as únicas feitas por Varnhagen antes de assumir seu novo posto. O caminho para a Venezuela mostrava-se sinuoso. O percurso seguido pelo diplomata e historiador o conduz primeiro a Londres e, evidentemente, ao Museu Britânico. ${ }^{66}$ Ele explora as coleçóes de manuscritos que não haviam sido catalogadas no inventário que Jorge Cezar de Figanière editara em 1853. O resultado - um catálogo intitulado Succinta indicação de alguns manuscriptos importantes relativos ao Brazil e Portugal - é publicado em 1863. ${ }^{67}$ Varnhagen não é apenas um descobridor de fontes, é também aquele que segue o movimento dos outros, que complementa seus trabalhos. Trata-se de uma vontade quase obsessiva de controlar os elementos que criam as condições da escrita da história do Brasil. Se não é o primeiro a detectar um determinado arquivo ou fonte, ele sempre acrescenta alguma coisa, corrige algo; a última palavra deve ser sua. 


\section{Sofrimento, justiça e verdade}

Finalmente, Varnhagen assume suas funçôes em Caracas no dia 16 de outubro de 1861. Também não fica muito tempo. Não obstante suas capacidades intelectuais, reais ou apenas supostas por ele, o fato é que não conseguiu resolver os litígios de fronteiras do Brasil com os países limítrofes sob sua responsabilidade diplomática. Por outro lado, obteve êxito na conclusão de alguns acordos com a Venezuela sobre navegação fluvial, comércio e extradição. Em maio de 1863, é transferido para Lima, sendo acreditado também junto aos governos do Chile e do Equador. Antes disso, em fevereiro do mesmo ano, o encontramos em Cuba, recém-chegado dos Estados Unidos. O objetivo principal dessa viagem era o de conhecer as plantações de tabaco e cana e os respectivos processos de fabricação do cigarro e do açúcar cubanos. Pensava em propor ao governo brasileiro novas fórmulas para aprimorar a produção desses produtos no Brasil, o que faz através de uma carta ao ministro da Agricultura, Cansansão de Sinimbú. ${ }^{68}$

A viagem a Cuba não o afastou de sua militância pela história. Assim, mesmo de passagem, crê ter localizado o porto no qual Colombo teria abordado:

no vacilábamos en créer que el puerto de esta primera recalada debia ser alguno de los varios que se encuentram en la costa, desde ma punta Lucrecia hasta el puerto de Gibára. - Pero habiendo en principios del año pasado hecho un viaje a Cuba, pudimos por inspeccion propia de la mayor parte de su costa septentrional, constituirnos en jueces mas competentes en la cuestion, i hoi no titubeamos ya en suponer que la recalada de Colon tuvo lugar en el puerto de Gibára. I de nuestra opinion son varios pilotos prácticos de la costa a quienes hemos leido les pasajes respectivos del Derrotero. ${ }^{69}$

Ele sabe porque viu; a autópsia dele e de outros é a garantia da opinião e da crença. Por fim, ainda em Cuba, Varnhagen compra com o prazer de um bibliógrafo e uma ponta de antiquário, um exemplar do editio-princeps da Lettera a Soderini, escrita, por Américo Vespúcio, supostamente em 1506. ${ }^{70}$ A ida aos Estado Unidos e à Cuba, no entanto, havia sido precedida por um passeio por boa parte da cadeia andina. Em missiva a d. Pedro II, enviada da ilha de S. Thomas, em 26 de janeiro de 1863, ele retraça seu périplo: 
cada vez mais dou graças aos Céus e a V.M.I. de me haverem concedido occasião para (sempre levando commigo barômetro, thermometro, bússola de geólogo e os quatro volumes do Cosmos, em que terei occasiāo de notar algumas equivocações) ver o Pacífico e grande parte dos Andes, junto de Quito, os nevados Cayambe, Antisana, Pichincha e Cotopaxi (vulcão ativíssimo), e donde, perto do Rio-Bamba, os tambem nevados perpétuos Chimborazo, Caranairazo, Tunguragua, Altar ou Capac-urecu e Cutilino, até os chilenos Tupungaro e Aconcagua, cujos píncaros culminantes, no estado actual da sciencia, disputam ao do Chimborazo a primazia de altura na América. Ainda que, Senhor, todo o resto dos meus dias me lembrarei do modo como passei no Equador (cordilheira do Puyal) um dia 2 de Dezembro e sua competente noite,... dormindo - todo molhado - ao relento e com o pobre animal ao meu lado sem ter que comer... ${ }^{71}$

Esta carta é extremamente representativa da vida e obra varnhageniana. Em primeiro lugar, o destinatário: nada menos que o imperador, o que não chega a ser uma novidade nesse período. Em segundo lugar, é necessário que se enfatize mais uma vez: a viagem apreendida como fundamento de seu duplo ofício. Viajar é uma etapa importante para a operação historiográfica de Varnhagen. As questōes diplomáticas, no fundo, somente são explicadas pela história ou pela geografia. Assim, não é surpreendente encontrá-lo munido dos instrumentos indispensáveis para fazer a cartografia do caminho por onde passa. Além disso, ninguém escapa à sua crítica. Ele não poupa nem mesmo Alexander Humboldt, sábio tão respeitado, sobre cuja obra nenhum dos membros do IHGB, anos antes, teve a ousadia de preparar uma resenha crítica. ${ }^{72}$ Com Varnhagen é diferente. Homem de estudos que não se restringe ao gabinete, ele simplesmente leva consigo o Cosmos para lhe corrigir alguns equívocos. ${ }^{73} \mathrm{O}$ método crítico, um olhar atento e uma boa dose de presunção acompanham seus movimentos. Há ainda nessa carta um pequeno detalhe que merece ser assinalado. O sofrimento do historiador. Para melhor conhecer seu país é preciso deixá-lo. Tal experiência é, por vezes, árdua. Não é raro encontrar-se submetido a condiçôes lastimáveis. Acontece-lhe mesmo de não encontrar lugar para dormir e até passar frio e fome, como nesse triste dois de dezembro, frisado na carta, pois não era outro senão o dia do aniversário do imperador. Varnhagen, sutilmente, lembra a d. Pedro II que no momento em que há festa na corte, ele trabalha. Por eles. 
Ao chegar a Lima, Varnhagen teve de enfrentar vários problemas. Além da questão da abertura de certos afluentes do rio Amazonas ao comércio mundial, o historiador vê-se envolvido em um grave affaire diplomático. Depois de passar alguns meses na Colômbia, ele conhece no Chile Carmen Ovalle y Vicuña, oriunda de uma família aristocrática chilena, com quem se casa em $1864 .{ }^{74}$ Nessa época, o Chile estava em conflito com a Espanha. O governo brasileiro, em guerra contra o Paraguai, não queria entrar em desavenças com outros países, e declara-se neutro. No entanto, em 31 de março de 1866, a Espanha bombardeia Valparaíso, provocando a reprovação geral na América espanhola. Varnhagen, claramente, toma posição a favor do Chile, "por respeito - diz ele - pela verdade e pela justiça". ${ }^{75} \mathrm{O}$ governo espanhol, por sua vez, interpretou o gesto do diplomata brasileiro "como uma prova de não equivoca imparcialidade". ${ }^{76}$ A chancelaria imperial censura Varnhagen. Ele procura defenderse afirmando que somente estava obedecendo "a superiores inspiraçóes de patriotismo, e altas conveniencias da nossa politica (se a queremos ter) nestes paizes, e a um elevado sentimento de justiça”, conforme relata em carta a Francisco Otaviano Rosa, em 10 de dezembro de 1865..$^{77}$ A posição brasileira, contudo, reforçou a tendência das repúblicas transandinas em considerarem que a única monarquia do Novo Mundo era uma nação que não apreciava a solidariedade continental, nem sustentava o "bom direito internacional" ${ }^{78}$

O que, enfim, explica a atitude de Varnhagen? Para Oliveira Lima, a resposta é simples: ele não era um bom diplomata:

Era um impulsivo com rompantes de colérico e que se deixava instigar por consideraçôes de eqüidade e de pundonor. Para ele a diplomacia não era a arte suprema de engolir desfeitas e disfarçar desaires. Achava-se compatível com a franqueza e a honestidade. Repugnava-lhe mentir, mesmo por conta de outros, e o que era justo não via muito bem por que devesse ocultá-lo. ${ }^{79}$

A performance negativa de Varnhagen como diplomata seria uma conseqüência lógica do seu vínculo com a verdade histórica e com os arquivos: tal como o historiador, o diplomata não mente. Clado Lessa, mesmo considerando que Varnhagen não podia ter tomado posição no conflito, contesta a afirmação de Oliveira Lima, pois o erro diplomático não teria 
comprometido o Brasil, e, além disso, assegurara a amizade dos chilenos. A hipótese de Lessa, sempre apologético em relação a Varnhagen, não é muito convincente. ${ }^{80}$ Por outro lado, o próprio Lessa sublinha uma questão que não é negligenciável: o apoio à causa chilena tivera, provavelmente, um ingrediente de ordem emocional; era o país natal de sua mulher.

As opiniōes sobre o papel diplomático de Varnhagen são, portanto, polêmicas. Mesmo sua noção de diplomacia é ambígua:

todos podemos errar, e há erros que merecem toda a contemplação, assim como há outros que fazem parte dos mysterios da diplomacia. E todo diplomata amante do seu paiz e por conseguinte da gloria, mais do que das suas commodidades e do seu soldo, deve estar sempre disposto para o sacrificio, e submetter-se a elle calado até que as explicações não compromettam. A diplomacia (se tal nome se lhe poderá dar) de completa abstenção seria mui facil, mui cômmoda, e mui egoista para os agentes; mas em tal caso o melhor era retiral-os, ou ser expressamente ordenada. ${ }^{81}$

Varnhagen tenta, de alguma maneira, justificar-se. Ele espera a indulgência graças à complacência do Império ou ao reconhecimento de que existem erros políticos que, na realidade, não passam de ações secretas, porém normais, dos agentes do corpo diplomático. Em todo o caso, ser diplomata é estar pronto a fazer sacrifícios (como o historiador nas montanhas!). Ou, por exemplo, ser punido por seu governo em razão de uma incompreensão. Todavia, se ao contrário, o ministro dos Negócios Estrangeiros brasileiro ou seus auxiliares mais diretos esperam de seus funcionários uma atitude completamente neutra, e se eles chamam isso de diplomacia, esta não parece ser a concepção que orienta o diplomata Varnhagen. Em diplomacia, não é necessário ser imparcial, pois, no final das contas, trabalha-se para uma nação. É suficiente ser justo e verdadeiro.

Justiça e verdade aproximam a figura do diplomata àquela do historiador, como sugere Oliveira Lima. No entanto, mesmo se os dois princípios são igualmente aplicáveis, a imparcialidade de um e de outro continua um problema para Varnhagen. Se o diplomata pode, ou de preferência deve, ser parcial, o mesmo não é válido para o historiador. Varnhagen sabe muito bem que os historiadores brasileiros não somente trabalham para a nação, assim como os diplomatas, mas que muitos deles são também 
remunerados pelo Estado. Essa situação, antes de ser um obstáculo à pesquisa científica, que devia ser imparcial, é uma condição indispensável para seu progresso. Além disso, como já vimos, muitas contendas fronteiriças, tema constante, naquela época, da agenda diplomática dos países na América Latina, eram resolvidas a partir do discurso histórico. A questão é como conciliar o diplomata parcial e o historiador imparcial. Trata-se de um assunto sensível em Varnhagen. Na polêmica, por exemplo, que mantém com Armand D’Avezac, geógrafo e ministro da Marinha e das Colônias da França, na Société de Géographie de Paris, entre 1857 e 1858, sobre os limites da Guiana com o Brasil, o tema da parcialidade/imparcialidade é retomado a partir do "ponto de vista" da nação. ${ }^{82}$ No entanto, nesse caso, o campo da disputa é aquele da ciência, embora, evidentemente, a dimensão política esteja longe de ser descartada. Trata-se de um geógrafo versus um historiador. ${ }^{83} \mathrm{O}$ problema chileno é de ordem inversa. Ele deveria restringir-se ao domínio das relações internacionais, mas a dimensão histórica ou científica nunca está ausente. Nesse sentido, até onde tive condições de avaliar, é possível se observar na obra de Varnhagen algumas referências à imparcialidade do historiador. Entretanto, encontramos sobretudo alusóes aos temas da justiça e da verdade. Esquematicamente, afigura-se lícito dizer que ser justo e verdadeiro é um efeito de sua formação erudita. São características normativas de todas suas atividades intelectuais. Isso não significa que eu o considere justo e verdadeiro, mas, simplesmente, que ele acreditava sê-lo. Porém, em muitas ocasiōes, parece-me que suas tentativas de ser parcial (enquanto diplomata) ou de ser imparcial (enquanto historiador) esbarram em uma disposição mais profunda, algo que as premissas políticas ou teóricas não conseguem assegurar ou conter: sua personalidade passional (eu sou brasileiro, então defendo nossas fronteiras; minha esposa é chilena, portanto, eu apóio a causa do Chile; meu pai é meu pai, então eu o insiro na história geral do Brasil...).

\section{Retorno aos arquivos, às fontes}

Quem poderia imaginar que Varnhagen, em meio às controvérsias diplomáticas das repúblicas latino-americanas, longe dos arquivos, e sobretudo da "civilização" européia, sentia-se, lá pelos idos de 1865, quase 
adaptado aos trópicos, não mais tão tristes. Casado, um filho de dois meses, confessava: "acho-me tão affeito a estes paizes que pouco ambiciono passar a servir na Europa” ${ }^{84}$ A sensação de bem-estar, contudo, foi passageira. Entre 1866 e 1867, o governo brasileiro separou a representação única que havia para o Equador, o Chile e o Peru. A partir de então, cada um desses países teria uma legação do Brasil. Varnhagen, em carta endereçada de Lima ao imperador, reconsidera a situação:

[...] ultimamente pouco tenho podido estudar no meio das lides e difficuldades da politica destes paizes. Espero que mediante o favor e justiça de V.M.I. chegará o dia em que poderei ser promovido a alguma Legação no Sul da Europa, ao menos em quanto ahí conclua a $2^{a}$ edição da minha obra, que, por muitos motivos, me fôra impossivel realizar nestes paizes. ${ }^{85}$

Regressar à Europa era, portanto, voltar às pesquisas. Ao retornar ao Rio de Janeiro, em função do rompimento das relações diplomáticas entre o Brasil e o Peru, envia nova carta, em 26 de outubro de 1867, ao imperador, onde reitera sua demanda de transferência para um país europeu. Ele enfatiza as razóes intelectuais de sua solicitação, lembrando que o desejo de terminar a segunda edição da sua Historia geral não era um desejo pessoal, mas uma maneira de ajudar a nação. Após, acrescenta: "Creio, Senhor, haver adquirido algum direito a fazer este pedido pelo modo como, para calar os gritadores, fui o primeiro a desejar, sem proferir a mínima reflexão em contrario, em 1858 e 1861, o servir algum tempo nas mesmas Repúblicas, começando pelo Paraguay.” Varnhagen explica também que mesmo que o governo brasileiro venha a restabelecer contatos diplomáticos com o Peru, sentia-se muito "gasto" para reassumir tal posto. Além do mais, encontrava-se "desprestigiado por uma mui conhecida desapprovação do Governo Imperial", quando de sua declaração favorável ao Chile. E pior ainda, é o fato de ser considerado "suspeito (Deus sabe que com muita injustiça) pela sua Mãi-Patria, como desaffecto a ella". A situação é tão desesperada e "repugnante" que Varnhagen prefere, no caso de uma resposta negativa a seu pedido, ser "posto em disponibilidade, ou mesmo ser demittido, do que em ter de ir para qualquer dellas", incluindo aí o Chile de sua mulher. Recorda ainda ao imperador que três colegas diplomatas mais jovens na carreira passaram-lhe adiante 
nas promoções. Não se sentia, contudo, menos habilitado que eles. Essa situação fora criada, segundo Varnhagen, pela inveja que inspira sua condição de "litterato e escriptor". Para combatê-los, o historiador "só contava com a protecção e justiça de V.M.I., que Sabe muito bem que quem escreve sempre tem de engendrar alguns compromettimentos" ${ }^{86}$

A essa altura da vida, Varnhagen sabe qual é a diferença entre ele e os outros diante do imperador. É a sua já imensa produção bibliográfica. Sendo assim, não hesita em fazer seus pedidos tendo por justificativa a necessidade de continuar suas pesquisas. É importante observar aqui sua afirmação de que contava apenas com a proteção do próprio monarca. Trata-se de uma manifestação reiterada diversas vezes pelo historiador, que foi quem, entre os homens de letras brasileiros, mais cartas enviou ao imperador. ${ }^{87}$ D. Pedro II, o sábio, era seu protetor, mas também uma espécie de interlocutor acadêmico. Com freqüência aparece na sua correspondência relatos diplomáticos, pedidos de ordem pessoal ou para um terceiro, mas ele escreve, sobretudo, para falar de suas atividades intelectuais. Se o imperador não acrescenta quase nada às suas obras, ao menos ele, supostamente, o lê, o escuta. As orelhas reais, como a de um psicanalista, compensavam um pouco a fria recepção que seus trabalhos tinham, em geral, no meio cultural brasileiro, especialmente no IHGB.

Varnhagen, efetivamente, foi criticado no Brasil menos por sua obra do que por sua personalidade. Há quase uma concordância entre os comentadores do historiador que sua existência não suscitava grande simpatia. A paranóia, que se nota na sua produção epistolar, bem como em torno das polêmicas geradas por seus estudos, não era totalmente desprovida de fundamento. Para alguns, ele não passava de um bajulador. Ter-se declarado um monarquista incondicional, não somente na sua correspondência com o imperador, nos seus relatórios para o ministério, mas também, publicamente, no interior de sua obra, em muito contribuiu para consolidar essa imagem. ${ }^{88}$ Também não é menos verdadeiro que o imperador tornou-se seu protetor. O clima de desconfiança, ao menos, que envolvia Varnhagen foi atestado por José Ricardo Moniz, ao que tudo indica um de seus poucos amigos, que conta como o historiador era visto pelos colegas do IHGB: "Os Pôrto-Alegres, Macedos, Joaquim Norberto que de longe o elogiavam, logo que ele deles se aproximou não o chamavam 
senão por um trapeiro. Varnhagen não se sentia bem no Instituto." ${ }^{89}$ Todavia, é em uma carta justamente de Manuel de Araújo Porto Alegre (que viria a ser padrinho do segundo filho de Varnhagen), datada de 26 de junho de 1851, endereçada a Paulo Barbosa da Silva, que encontrei de modo mais clara a descrição das relações de Varnhagen com o imperador e a percepção que dele tinham certos membros da corte imperial: "Acha-se aqui o Varnhagen, que tem sido muito festejado, e a quem aconselhei que se safasse o mais breve possível, pois se poderia azedar dentro da vinagreira. S.M. o tem tratado com muita distinção." ${ }^{90}$ As opiniōes e o apoio de d. Pedro II funcionavam como recursos práticos (sobretudo financeiro, pois Varnhagen era apenas um assalariado do Estado, que se lamentava freqüentemente dos baixos vencimentos que recebia) e como uma forma simbólica de se fazer aceito social e culturalmente. Varnhagen, além de brasileiro, era o historiador que mais havia contribuído para a história brasileira. Em todo o caso, a nação, no seu grau mais elevado, parecia reconhecer nele alguém cuja importância, sobretudo intelectual, era incontestável.

Intrometido, infeliz e, finalmente, nobre

Em 22 de fevereiro de 1868, por um decreto imperial, Varnhagen é transferido para a Áustria, como ministro residente na corte de Francisco José I. Voltará apenas uma vez ao Brasil, antes de sua morte. As repúblicas da América Latina tornam-se apenas matéria mnemônica e, apesar das queixas sobre a dificuldade em pesquisar, notas abundantes. Em Viena, Varnhagen pode retomar seus estudos com o tempo e calma que julgava necessários, pois o Brasil também não tinha questões diplomáticas relevantes para tratar com o governo austríaco.

Antes de se instalar definitivamente, aproveita a viagem para revisitar alguns países europeus. Em Lisboa, toma contato com a obra de Richard Henry Major sobre o infante d. Henrique, o navegador. ${ }^{91}$ Em desacordo com o inglês, escreve uma carta para contestá-lo. Os pontos de discordância não eram muito significativos, o que não impediu que a controvérsia obtivesse, durante algumas semanas, um certo destaque no Jornal do Comércio de Lisboa. ${ }^{92}$ 
Ainda na capital portuguesa, visitou os trabalhos de restauração do monastério de Belém, efetuados sob a direção do arquiteto Joaquim Possidônio Narciso da Silva. Quando jovem, o historiador fizera estudos de arquitetura, chegando mesmo a escrever um trabalho sobre os monumentos portugueses. ${ }^{93}$ Não satisfeito em apenas visitar o local, Varnhagen faz algumas observações críticas ao projeto do arquiteto. Já em Viena, o historiador responde a uma longa carta de Narciso da Silva, e sem constrangimento dá-lhe uma série de sugestões. ${ }^{94}$

Depois de Lisboa, seu destino é Paris, mais precisamente a Biblioteca Imperial, onde analisa o mapa atribuído a Gaspar Viegas de 1534, cuja existência teria sido revelada por Ferdinand Denis. Para Varnhagen, o mapa nada tem de original e questiona mesmo sua autoria. Por outro lado, encontra dois outros mapas, esses, para ele, autênticos, assinados por Jacques de Vau de Claye em 1579. Em carta ao então primeiro-secretário do IHGB, Joaquim Caetano Fernandes Pinheiro, remetida de Viena em 20 de julho de 1868, noticia a descoberta e exibe uma interpretação acerca de seus conteúdos, concluindo que eram "do maior interesse histórico". 95

Após Paris, Varnhagen chega enfim a Viena, assumindo suas funçóes como ministro residente em 4 de julho de 1868. Viena, segundo Clado Lessa, teria sido uma escolha do próprio Varnhagen. No entanto, os primeiros tempos não parecem ter sido fáceis. É com o imperador, mais uma vez, que extravasa suas angústias:

Sinto-me nervoso, doença que nunca soffri, e toda a applicação me cança e me causa tédio, inclusivamente a dos estudos históricos, cujos trabalhos aturados eram antes para mim um encanto em que passava o tempo sem o notar! Se sigo neste andar, com semelhante relaxação do espirito por outro anno mais, creio que me despedirei das lettras, e começarei nellas a duvidar de mim mesmo[... $]^{96}$

Alguns meses depois, as queixas aumentam. Varnhagen não se sente à vontade na capital austríaca. Ele gostaria de ter mais prestígio. Para tanto, solicita a d. Pedro II trocar de posto com o ministro brasileiro em Bruxelas, que por sua vez gostaria de ir para Viena:

Desta maneira se conciliaria tudo, eu e o Sr. Brito seríamos attendidos em nossas aspiraçõos, e o serviço ganharia; pois a consciência me diz que, fó- 
ra da Allemanha me encontrarei sempre menos apoucado e poderei fazer mais figura. E nesta convicção até nem me atrevi applicar-me de novo ao allemão, que ao chegar aqui reconheci que havia quasi de todo esquecido. ${ }^{97}$

Acrescente-se às inibições sociais e à dificuldade com a língua, o problema econômico. Viena era uma cidade cara para alguém como Varnhagen. ${ }^{98}$ Em outra carta ao imperador, de 21 de outubro de 1870 , que principia com um lamento deprimido acerca da morte da filha de apenas três anos, ele aproveita mais uma vez para informar ao soberano que a situação tornou-se tão difícil que decidiu "adoptar o único systema possivel, para soffrer menos das humilhaçôes officiaes; systema que consistiu em procurar representar menos, e manter-me na maior reserva e modestia possivel". ${ }^{99}$ Além disso, sua produção historiográfica estava paralisada, pois tinha de fazer tudo no ministério. Pobre Varnhagen!

Parece que sua elevação ao posto de ministro plenipotenciário, em 15 de abril de 1871, alterou significativamente o quadro. Ele retoma o trabalho, sobretudo as pesquisas históricas e etnológicas e publica a Historia das luctas com os Hollandezes, já anunciada na primeira edição da sua Historia geral. Nesse mesmo ano, d. Pedro II faz sua primeira viagem à Europa. Varnhagen, ansioso, relata ao imperador que estava contando os dias para sua chegada a Viena. ${ }^{100}$ No ano seguinte, obtém uma licença do Ministério dos Negócios Estrangeiros brasileiro e parte para Lisboa a fim de explorar, ainda uma vez, os arquivos e as bibliotecas da cidade, momento em que toma conhecimento das primeiras críticas ao romantismo português, feitas, principalmente, por Theophilo Braga e Adolpho Coelho contra Castilho, Garret etc. Varnhagen intromete-se na polêmica. ${ }^{101}$ Ainda em 1872, devido a uma participação ativa no congresso de estatística de São Petersburgo é eleito um dos vice-presidentes da "Comissão permanente". ${ }^{102}$

O já barão de Porto Seguro, em 1873, consagra parte de seu tempo aos preparativos da Exposição Universal em Viena, da qual se torna também um dos vice-presidentes do júri. ${ }^{103} \mathrm{Em} 1874$, o então visconde de Porto Seguro, aproveitando-se da condição de membro da comissão de estatística, faz uma viagem para a Escandinávia. Explora, como de hábito, museus, arquivos e bibliotecas. Em Copenhague, no museu das Antiguidades do Norte, localiza na coleção de etnografia dinamarquesa os qua- 
dros de A. Eckhout, que fazia parte da comitiva de Maurício de Nassau, e que pintara índios, negros e mestiços brasileiros. Varnhagen teria sido o primeiro a chamar a atenção de d. Pedro II para esses quadros, que mais tarde mandou copiá-los. Por fim, em 1876, participa em Budapeste de dois eventos científicos: outro congresso de estatística, no qual apresenta um trabalho; ${ }^{104}$ e do congresso, assim chamado, pré-histórico. Além disso, publica aquela que é sua obra mais enigmática, escrita em francês (para atingir um público mais amplo), intitulada L'Origine Touranienne des Américains Tupis-Caribes et des Anciens Egyptiens, onde procura provar, através da filologia comparada e da etnografia, que a origem dos índios brasileiros encontrava-se no mundo antigo. ${ }^{105}$ Nosso colega, agora sênior, não dava sinais de estar perdendo a forma.

\section{A última autópsia}

"Vista faz fé." (Varnhagen) ${ }^{106}$

"Antes de escrever, Varnhagen viu." (Ferdinand Denis) ${ }^{107}$

“Tudo viu, tudo examinou." (Capistrano de Abreu) ${ }^{108}$

No início de 1877, Varnhagen publica, enfim, a segunda edição da História geral. Um episódio narrado nela é, de certo modo, responsável por sua última viagem ao Brasil. No capítulo sobre a ocupação do Rio de Janeiro pelas tropas do francês Duguay-Trouin, o historiador afirma que "a primeira lição que devemos colher" é que a capital do Império não podia continuar sediada na cidade do Rio de Janeiro. ${ }^{109}$ Desde o Memorial orgânico de 1849 o assunto preocupava-o. ${ }^{110}$ Para dirimir com a maior brevidade possível a questão, solicita ao governo uma licença de seis meses e parte para o Brasil. Em seu retorno a Viena, escreve um opúsculo específico sobre o tema: A questão da capital: maritima ou no interior?, cuja epígrafe, de Foissac, é reveladora de sua intenção: "Que influencia não exerce a posição de uma cidade sobre o destino de um povo inteiro! As vezes por ella se explicará a elevação de uma nação." ${ }^{111}$ Nesse pequeno texto, retoma as consideraçóes que fizera sobre o assunto na nova edição da Historia geral: 
Publicadas estas linhas, o proprio accento de convicção que ellas respiram fez estremecer a nossa consciencia timorata, em presença da responsabilidade tomada, em tal obra, ante a posteridade. Figurou-se-nos que não ficariamos tranquillos enquanto, por nossos proprios olhos, nos não desenganassemos de todo, e à mesma posteridade, se tinhamos ou não razão em todos os nossos planos e propostas engendradas sobre o papel, no silencio do gabinete. ${ }^{12}$

No Brasil, percorre mais uma vez a região onde nasceu. Após, encaminha-se em direção a Goiás. Trabalho e sacrifício ditam novamente o ritmo do movimento do investigador:

emprehendemos (levando comnosco os competentes instrumentos, incluindo nada menos que tres barometros) à custa de quaesquer trabalhos e sacrificios, em quanto para elles nos sentiamos com fôrças, uma penosa viagem a cavallo, nada menos que até à provincia de Goyaz, por nossas primitivas estradas, para de visu e como antigo engenheiro, reconhecer essa notavel paragem que a contemplação e estudo dos melhores mappas nos havia revelado. ${ }^{113}$

Para conhecer, reconhecer e assim abastecer a capacidade descritiva é preciso antes ver, mas com olhos afiados, criteriosos, poderíamos dizer científicos, como os de um "antigo engenheiro". O resultado são descrições que mostram como a situação do Brasil profundo não alterara-se muito desde as viagens de John Mawe, de Spix e de Martius, de Neuwied ou de Saint-Hilaire, entre outros, durante os anos 1810-20. A despeito das dificuldades do itinerário, o historiador considera seus resultados proveitosos. Não somente confirma o lugar propício, no seu entender, para a instalação da capital, sobre a qual tinha um "pressentimento bem apoiado em dados geográficos”, como o considera acima de suas expectativas. Além disso, a região era apropriada à colonização européia, da qual era um infatigável defensor.

Antes de voltar à Europa, passa pela Bahia. Varnhagen queria conhecer Porto Seguro e Ilhéus. Nessas cidades, realiza pesquisas com o objetivo de encontrar as fontes das respectivas fundações. Encontra alguns documentos, mas decepciona-se com o péssimo estado de conservação em que se encontravam. A viagem, contudo, não fora inútil, mas "de grande 
vantagem" porquanto o "conhecimento individual" que fez delas - dessas "duas localidades, núcleos de duas de nossas capitanais primitivas" ampliará sua capacidade de escrever a história: "melhor poderei descrever para o futuro." $114 \mathrm{O}$ olho, como diria Foucault, "torna-se o depositário e a fonte da clareza". ${ }^{115}$ Não se trata apenas de uma compensação à inexistência de documentos acessíveis ou confiáveis, mas de um expediente cognitivo: isto é, a visão aparece não como um último recurso, mas como instrumento de saber; portanto, não como uma metodologia alternativa, mas como fundamento epistemológico da pesquisa. Ou seja, não é buscar no presente os traços do passado de uma forma instantânea e irrefletida; a autópsia não é, em Varnhagen, um dado imediato da consciência e sim um trabalho intelectual que requer conhecimento anterior e uma constante interlocução entre a inatualidade pretérita e o presente.

\section{A morte e o cuidado de si}

Varnhagen tinha a intenção de um dia "depois de acabar a nossa Historia da Independência", publicar o diário desta viagem - na qual inclusive acreditava ter encontrado o local exato da chegada de Cabral e da celebração da primeira missa - e "(que resultou até em proveito de nossa saúde), com as observações feitas, especialmente com respeito a ortographia dos pontos percorridos, na ida e na volta; o que tudo apontávamos em cada noite, apezar das fadigas do caminho, e depois de haver andado, desde às $6 \mathrm{da}$ manha, às vezes oito e nove leguas" ${ }^{116} \mathrm{O}$ historiador-viajante não teve tempo de escrevê-lo. As vicissitudes da viagem provocaram-lhe uma doença fatal. Em 29 de junho de 1878, com 62 anos, o visconde de Porto Seguro morre em Viena, longe, como sempre, de sua terra natal. ${ }^{117}$

Em seu testamento consta a orientação de que no local de seu nascimento fosse erigido um monumento à sua memória. Quatro anos após sua morte, nas terras da Real Fabrica de Ferro de São João de Ipanema, sua vontade é atendida. Em uma das faces do pedestal se lê a seguinte inscrição: "À memória de Varnhagen, Visconde de Pôrto Seguro, nascido na terra fecunda descoberta por Colombo, iniciado por seu pai nas coisas grandes e úteis. Estremeceu sua Pátria e escreveu-lhe a História. Sua alma imortal reúne aqui tôdas as suas recordações." ${ }^{118}$ Não se sabe quem escre- 
veu esse epíteto. Pode ter sido um amigo, um admirador, alguém da família ou o próprio Varnhagen. Seja como for, a solicitação do historiador não precisa ser percebida apenas como um reflexo egocêntrico, mas talvez como uma atitude preventiva. Tudo indica, a partir do que se sabe sobre sua vida, que Varnhagen tinha consciência de não ser muito popular em seu país, e que desconfiava da fidelidade de seus colegas em preservar sua memória. Ele sempre reivindicou que a pátria reconhecesse seus grandes homens. Parece que não mudou de opinião, mesmo após a morte! Eis aqui, mais uma vez, um dos limites do paradoxo varnhageniano que vimos tentando demonstrar ao longo deste ensaio: o melhor historiador da nação tinha dificuldades em ser reconhecido como desejava, sobretudo no IHGB; o grande patriota que não está quase nunca na sua pátria. José Veríssimo é um dos poucos comentadores de Varnhagen a chamar a atenção para essa aparente contradição:

Consagrou toda a sua laboriosa existência a estudar a história do Brasil, e a servi-lo com dedicação e zelo em cargos e missões diplomáticos. Sente-selhe, entretanto, não sei que ausência de simpatia, no rigor etimológico da palavra, pelo país que melhor que ninguém estudou e conhecia, e era o do seu nascimento. Não é patriotismo, entenda-se, que lhe desconhecemos, esse o tinha ele, como qualquer outro e do melhor. Faltava-lhe, porém, não lho sentimos ao menos, aquele não sei quê íntimo e ingênuo, mais instintivo que raciocinado, sentimento da terra e da gente. Ele não tem as idiossincrasias do país. ${ }^{119}$

Nota-se, tanto na sua correspondência quanto na sua obra, que Varnhagen passa boa parte de sua vida procurando resolver essa ambigüidade, ou, no mínimo, a dominar esse sentimento de desterrado. Ele procura estabelecer uma ligação constante, uma coerência íntima entre os termos contraditórios de sua existência, como brasileiro (levando-se em consideração que ele é o único em seu núcleo familiar - filhos nascidos no estrangeiro, esposa estrangeira, filho de estrangeiro...) e como historiador da nação. ${ }^{120}$ A imensa obra dedicada ao Brasil não seria uma maneira, para ele, de estar sempre entre os brasileiros? "Toda a modestia não é bastante para que eu não reconheça que a Historia do Brazil, ao menos em muitos de seus períodos, fica com a minha obra de uma vez escripta, e que ella viverá (a obra) eternamente, e fará eternamente honra, ao Brazil e ao reinado de 
Seu Excelso Proctetor." ${ }^{121}$ Como a obra de Tucídides: uma aquisição para sempre. ${ }^{122}$ Parece-me que o conjunto dos trabalhos e daquilo que se sabe sobre sua vida (há muito a ser explorado) pode ser interpretado como tentativas de organização de duas temporalidades distintas e simultaneamente imbricadas: a da história do Brasil e a da sua biografia. O mesmo cuidado em atribuir um sentido à história da nação, seu passado, presente e futuro, ele tem consigo. A história é um instrumento desse duplo reconhecimento. Com ela se conhece, se compreende. Com ela, Varnhagen prova sua nacionalidade e a do próprio país. A historiografia varnhageniana encerra, assim, um drama de ordem psicológica particular, onde tudo se confunde constantemente: ao mesmo tempo resposta a uma questão existencial e uma tentativa de explicação às necessidades, conscientes ou inconscientes, do Brasil: quem somos? De onde viemos? Sua obra, sua carreira diplomática, seus abundantes escritos epistolares, seu testamento, que são elementos constituintes deste discurso do oitocentos que chamo de retórica da nacionalidade, participam de uma lógica, ao mesmo tempo, retrospectiva e prospectiva, por meio da qual é possível se perceber a consistência e a constância que ele desejava conferir a sua existência. Estratégia de ação que não passa de uma ilusão biográfica? ${ }^{123}$ Não estou certo. Parece-me que, mais do que projetar uma simples ilusão, os traços da vida e o conjunto da obra de Varnhagen revelam se não uma crença pessoal em quem ele era, o que ele representava de fato e o que poderia vir a representar, ao menos uma sólida intenção de não apenas inventar uma biografia, mas também de protegê-la, enfim, uma vontade intensa de cuidar de si.

Do homem-monumento ao homem-inteiriço: entre a ironia e o reconhecimento

\section{A ironia}

A morte de Varnhagen provocou, evidentemente, certas reações, sobretudo no IHGB. Durante a sessão de aniversário da instituição, em 15 de dezembro de 1878, Joaquim Manuel de Macedo, então primeiro-secretário, no seu necrológio dedicado a Varnhagen afirma, em meio a várias críticas, que o historiador recém-falecido teria sido, pelos seus tra- 
balhos históricos, um "homem-monumento". ${ }^{124}$ A definição de Macedo foi interpretada pelos comentadores, críticos ou apologistas de Varnhagen de diferentes maneiras. Para Basílio de Magalhães e Clado Lessa, trata-se de um grande elogio e de uma avaliação positiva da obra varnhageniana. ${ }^{125}$ Já Agripino Grieco vê na fórmula de Macedo uma fina ironia, pois Varnhagen,"mais do que um homem, era uma estátua", aliás, "lemo-lo com proveito mas nenhum prazer temos em lê-lo, e muito menos nos daria prazer o tê-lo por vizinho ou fazer em companhia dele uma longa viagem por terra ou por mar". ${ }^{126}$ A expressão de Macedo, acompanhada também de um dos primeiros julgamentos da obra de Varnhagen e os comentários nada elogiosos de Grieco, nos conduzem a uma última característica desta breve antologia de sua existência: seu caráter suscetível, principalmente quando sua obra era objeto de reparos.

Na notícia necrológica sobre Varnhagen, publicada no Jornal do Commercio de 16 e 20 de dezembro de 1878, Capistrano de Abreu sintetiza os termos da crítica subseqüente. Após alguns elogios à obra do visconde de Porto Seguro, observa que

Tambem elle tinha muitos pontos vulneraveis. Era dos homens inteiriços, que não apoiam sem quebrar, não tocam sem ferir, e matam moscas a pedradas, como o urso do fabulista. Em muitos pontos em que a sua opinião não era necessaria, elle a expunha complacentemente, com tanto maior complacencia quanto mais se afastava da opinião commum. Suas reflexôes às vezes provocam um movimento de impaciencia que obriga a voltar a pagina ou a fechar o volume. Muitos assumptos sem importancia, ou de importancia secundaria, só o occupam por serem descobertas suas. A polemica com João Lisbôa, em que tinha talvez razão, porém em que teve a habilidade de pôr todo o odioso de seu lado. Homem de estudo e de meditação, desconhecia ou desdenhava muitas das tyranias que se impõem com o nome de conveniencias; sensivel ao vituperio como ao louvor. ${ }^{127}$

Do homem-monumento ao homem-inteiriço define-se um perfil de críticas a Varnhagen. Se o necrológio de Macedo abriu espaço para exames mais atentos à personalidade de Varnhagen, o de Capistrano de Abreu, restrito às características pessoais do historiador que tem relação com a sua obra, inauguraram uma forma de avaliação mais ponderada e criteriosa. 


\section{$\mathrm{O}$ reconhecimento}

Os dois artigos de Capistrano de Abreu, de 1878 e 1882, são importantes também por patrocinarem o retorno da obra varnhageniana ao primeiro plano da historiografia brasileira. Em 1903, ao escolher o nome do visconde de Porto Seguro como patrono de sua cadeira na Academia Brasileira de Letras, Oliveira Lima reforça essa tendência. Ainda no início do século XX, em 1906, Capistrano de Abreu começa mas não termina a revisão para uma nova edição da História geral do Brasil, que será concluída quase vinte anos depois por Rodolfo Garcia. Em 1916, o IHGB publica pela primeira vez o trabalho inédito de Varnhagen sobre a História da independência do Brasil. Nesse mesmo ano, na ocasião do centenário do seu nascimento, Pedro Lessa profere um discurso no IHGB, no qual enfatiza a relevância da obra de Varnhagen. Em São Paulo, ainda em 1916, Remigio de Bellido publica uma das biografias mais detalhadas do historiador até aquele momento. ${ }^{128}$ Em 1923, é fundado em São Paulo o Instituto Varnhagen, de efêmera duração. Varnhagen teve direito também a uma sala no IHGB com o seu nome. Seu retrato, em 1919, foi colocado na biblioteca do Ministério dos Negócios Estrangeiros do Brasil, e, em 1944, na galeria dos historiadores no Arquivo Nacional do Rio de Janeiro. O cinqüentenário de sua morte, em 1928 (ano da publicação da terceira/quarta edição da História geral), não foi esquecido pelo IHGB. Em 1937, durante a cerimônia de lançamento da pedra fundamental de um monumento em homenagem a Varnhagen, Affonso Celso, então presidente do IHGB, declara:

Na primeira glorificação pública a Varnhagen manda a justiça que mencione nomes ligados ao dele - os dos anotadores da edição completa da História geral-Capistrano de Abreu e Rodolfo Garcia, sem esquecer os seus principais apologistas, membros do Instituto: Barão do Rio Branco, Oliveira Lima, Basílio de Magalhães, Max Fleiuss. Colocando a efígie de Varnhagen num dos mais lindos e notórios sítios centrais da metrópole magnífica, quer o Instituto dar-lhe significação simbólica; sugerir ao povo a idéia de que a investigação conscienciosa do passado pátrio - lição profícua para o presente, incutidora de suspiciosa confiança no porvir - basta a tornar benemérito da mesma História, imortalizado, quem a isso se consagre, como Varnhagen. ${ }^{129}$ 
A declaração do presidente do IHGB recorda algumas funções da história ilustrada pela experiência varnhageniana. A primeira "glorificação pública” tem por objetivo não somente prestar homenagem ao historiador, mas também instruir o "povo", do qual ninguém era mais distante do que Varnhagen. ${ }^{130}$ Contudo, o essencial é que sua produção historiográfica simbolize a idéia de que a pesquisa séria é recompensada pela própria história. A estátua de Varnhagen é assim passível de ser percebida como um símbolo material da historia magistra vitae. A inauguração do monumento ocorre durante as comemorações do centenário da fundação do IHGB, em 21 de outubro de 1938: um busto em hermes no Jardim da Glória. Seguem-se outras homenagens ao historiador, sendo uma das mais significativas a transferência, em 1978, dos seus restos mortais, que estavam no Chile. Eis a inscrição da placa comemorativa:

Monumento: Francisco Adolfo de Varnhagen; Local: Avenida Gal. Osório; Data da inauguração: 29 de junho de 1978; Escultor: Ernesto Biancalana; Dizeres da placa: 'Estão aqui depositados os restos mortaes de Francisco Adolfo de Varnhagen, Visconde de Porto Seguro. Paulista de Sorocaba, o pai da história do Brasil (17/2/1816 - 29/6/1878). Transladados de Santiago, Chile, no centenário do falecimento. 29/6/1978. ${ }^{131}$

O homem-monumento, o homem-inteiriço, o pai da história do Brasil está finalmente em casa. Nada podia ser de melhor para um obstinado pelas origens. Ser colocado no início da cadeia historiográfica brasileira é a materialização de sonhos nunca abertamente revelados, mas dos quais deixou muitos indícios. Capistrano de Abreu dizia que Varnhagen, como Alexandre Herculano para a história portuguesa, "teve que fazer quase tudo". ${ }^{132} \mathrm{O}$ reconhecimento pelos historiadores do fim do século XIX e início do século XX das dificuldades do trabalho histórico operado pelo IHGB e por Varnhagen deve ser relacionado à proximidade temporal deles com os iniciadores. A produção científica da história estava apenas dando seus passos iniciais. Capistrano de Abreu, portanto, assinalou bem, não a origem da narrativa historiográfica, mas um determinado começo: Varnhagen. ${ }^{133}$ Ele é datado, localizado, visível, preso ao tempo dos homens e da ciência. E como todo discurso científico tem necessidade de um marco fundador, de um início, Varnhagen é adaptado a essa condição 
primordial. O que houve antes dele, dispersa-se diante do gigantismo de sua obra. No melhor dos casos tornam-se fontes históricas, no limite crônicas, no pior, esquecimento. Varnhagen passa a desempenhar para a história do Brasil o mesmo papel que Cícero atribuiu a Heródoto em relação à história: pai. A historiografia do fim do século XX, quer dizer, a historiografia acadêmica, não se preocupou muito em desmentir ou desqualificar essa analogia. ${ }^{134} \mathrm{O}$ uso de modelos da historiografia clássica com o objetivo de legitimar a primazia de um moderno através da sua identificação com um antigo está longe de ser um procedimento incomum, embora Heródoto também tivesse a fama, vinda igualmente da Antiguidade, de mentiroso. ${ }^{135}$ Até agora nada encontrei que permitisse estender essa comparação a Varnhagen, que no máximo é acusado de exageros e erros, alguns provenientes de uma concepção narcisista da história. Finalmente, além da paternidade reconhecida, uma outra característica em comum é possível de ser estabelecida: tanto o antigo como o moderno eram viajantes e suas obras não podem ser dissociadas dessa experiência, do movimento constante que ela implica. ${ }^{136}$ Por outro lado, não deixa de ser curioso que Varnhagen não tenha sido comparado, até onde eu saiba, por sua preocupação com a verdade e com uma narrativa pretensamente isenta escrita por um autor que se quer "ausente", a Tucídides, modelo de historiador para os eruditos do século XIX, inclusive para o imperador. Ele, tal como Tucídides, até escreveu uma história de seu tempo presente, embora o brasileiro não a tenha publicado em vida. ${ }^{137}$

\section{A história dos vencedores e um historiador vencido?}

'Historia geral', historia que, em serviço do paiz, mais que das lettras, correria já esta hora publicada com muitos melhoramentos e addições, se, em virtude de certas injustiças soffridas, nos não encontrassemos, aos cincoenta e tantos annos, com o animo quebrantado, e sem valor de lançar-se a novas emprezas, que lhe tragam decepções, em vez de estimulos. (Varnhagen) $)^{138}$

Varnhagen escreveu, segundo ele, a história da colonização portuguesa no Brasil. Uma história da vitória da civilização sobre a barbárie. A história da construção da nação brasileira. Uma história, portanto, dos ven- 
cedores. Mas o próprio Varnhagen seria um vencedor? Sua luta para ser reconhecido, em primeiro lugar como brasileiro, após como historiador e diplomata, finalmente como nobre, não foi exatamente um empreendimento pessoal bem-sucedido. É preciso lembrar que Varnhagen é brasileiro por decreto imperial. Sua carreira diplomática, pelos postos que ocupou, é aparentemente um sucesso, mas tanto na América Latina como na Europa ele lamenta as atribulaçóes e dificuldades, que, mesmo inerentes à diplomacia, são encaradas por ele muitas vezes como um fardo que o desvia do principal: suas pesquisas. Varnhagen também nunca foi um político, mesmo que algumas de suas obras tenham tido a pretensão de intervir diretamente no destino do país. Seu enobrecimento é tardio, quase no fim de sua vida. E sua obra impõe-se antes por ser a tal da "massa ciclópica de fontes acumuladas" do que por uma aceitação refletida e consensual de seus colegas, membros do IHGB ou não. Além disso, ele praticamente nunca estava no Brasil, estava sempre em movimento. Vivendo uma espécie de exílio voluntário imposto por sua vida de diplomata e pela incessante busca de arquivos, seu pertencimento à nação se faz mais pela obra do que pelo indivíduo. Varnhagen poderia dizer como Michelet: "Meu livro me criou. Eu fui sua obra. Esse filho fez seu pai."139

Creio que Varnhagen escrevia a fim de ter uma identidade: ser brasileiro. Não um brasileiro qualquer, mas um dos grandes. Aliás, ele nunca escondeu, da mesma maneira que os metódicos da escola de Gabriel Monod, que escrevia a partir de um "ponto de vista", no caso "brasileiro". ${ }^{140}$ Podemos nos perguntar então se Varnhagen, existencialmente, não teria escrito do ponto de vista de um vencido? Ele não teria, para retomar a expressão de Koselleck, "o saber de um vencido existencial"? ${ }^{141}$ A hipótese do historiador alemão, segundo a qual "a experiência que tiramos de uma derrota concentra um potencial de conhecimento que sobrevive àquilo que a ocasionou, em particular quando em razão de sua própria história o vencido é coagido a reescrever uma história geral", e que "desta maneira, pode-se explicar bom número de inovaçôes no domínio das interpretações históricas na origem das quais encontramos tanto derrotas pessoais como pressōes de experiências específicas de gerações inteiras", ${ }^{142}$ não parece ser aplicável à obra e à existência de Varnhagen? 


\section{Notas}

${ }^{1}$ VARNHAGEN, F. A. de. Correspondência ativa, organizada por Clado Lessa, RJ, INL/ MEC, 1961, p. 208-210 (a partir daqui CA). Agradeço a colega Maria da Glória Oliveira pelas sugestões a uma primeira versão deste trabalho, e a Fernando Nicolazzi, pelos comentários e revisão técnica do texto. Este artigo é dedicado aos meus alunos do seminário de Historiografia Brasileira (2006/II).

${ }^{2}$ BARTHES, Roland. Michelet. Paris, Seuil, 1995, p. 22-23.

${ }^{3}$ As biografias de Varnhagen não são numerosas, e as existentes, além de repetitivas, são, de modo geral, laudatórias. $\mathrm{O}$ trabalho mais completo e rico em informaçôes, porém acrítico em relação à obra varnhageniana, é o de Clado Lessa, ver Revista do IHGB, volumes 223, 1954, p. 82-297; 224, 1954, p. 109-315; 225, 1954, p. 120-293; 226, 1955 , p. $3-168 ; 227,1955$, p. 85-236. Por outro lado, Varnhagen tem muitos comentadores, começando por Capistrano de Abreu cujos artigos são fundamentais para o presente ensaio: "Necrologio de Francisco Adolpho de Varnhagen, Visconde de Porto Seguro", e "Sobre o Visconde de Porto Seguro (1882)", apud VARNHAGEN, F. A. de. História geral do Brasil, 3 $4^{\mathrm{a}}$ edição, SP, Melhoramentos, 1928, respectivamente tomo I, p. 502-508 e Appenso p. 435-444. Essa edição, organizada e comentada por Capistrano de Abreu e Rodolfo Garcia, reproduz a segunda edição da Historia geral do Brazil de 1877. (A partir daqui $H G B$, apenas especificando o volume, a edição e o ano). A lista que segue, embora não exaustiva, é significativa do interesse que a obra do historiador tem provocado nas últimas décadas: RODRIGUES, José Honório. "Varnhagen, mestre da história geral do Brasil”, Revista do IHGB, 1967, p. 170-196; SCHWARTZ, Stuart B. "Francisco Adolfo de Varnhagen: diplomat, patriot, historian", The Hispanic American Historical Review, may, 1967, vol. XLVII, no 2, p. 185-202; ODÁLIA, Nilo. "Introdução", Varnhagen, SP, Ática, 1979, p. 7-31; ODÁLIA, Nilo. As formas do mesmo. Ensaios sobre o pensamento historiográfico de Varnhagen e Oliveira Vianna, SP, Edunesp, 1997; MARTINIÈRE, Guy. "Problèmes du développement de l'historiographie brésilienne", Storia della storiografia, Milano, 19, 1991, p. 117-146; SCHAPOCHNIK, Nelson. Letras de fundação: Varnhagen e Alencar - projetos de narrativa instituinte, Dissertação de Mestrado, PPG em História Social, USP, 1992, 245p.; VASQUEZ, George L. "Varnhagen, Francisco Adolfo de. (1816-1878)", WOOLF, D. R. (editor), A global encyclopedia of historical writing, vol. II, New York and London, Garland Publishing, 1998, p. 917; AMBROSIO, Ubiratan. "Varnhagen, Francisco Adolfo de. - 1816-1878: Brazilian historian”, BOYD, Kelly. (ed.) Encyclopedia of historians and historical writing, vol. 2, London/Chigago, Fitzroy Dearborn Publishers, 1999, p. 1253-1254; REIS, J. C. "Varnhagen (1853-7): O elogio da colonização portuguesa”, Varia história, Belo Horizonte, no 17, mar/1997, p. 106-131, reproduzido em REIS, J. C. “Ano 1850: Varnhagen. O elogio da colonização portuguesa", As identidades do Brasil. De Varnhagen a FHC, RJ, 1999, p. 23-50; WEHLING, A. Estado, história e memória: Varnhagen e a construção da identidade nacional, RJ, Nova Fronteira, 1999; GUIMARÃES, Lúcia Paschoal. "Francisco Adolfo de Varnhagen. História geral do Brasil’, MOTA, Lourenço Dantas. Introdução ao Brasil. Um banquete no trópico, SP, SENAC, 2001, p. 75-96; PUNTONI, Pedro. "O Sr. 
Varnhagen e o patriotismo caboclo: o indígena e o indianismo perante a historiografia brasileira”, JANCSÓ, István. (org.) Brasil: formação do Estado e da Nação, SP-Ijuí, Hucitec/EdUnijuí, 2003, p. 633-675.

${ }^{4}$ A idéia de um movimento dentro da obra apareceu-me durante a leitura do excelente ensaio de Starobinski sobre Montaige, ver STAROBISNKI, Jean. Montaigne en mouvement, Paris: Gallimard, 1982, p. 8.

${ }^{5}$ VARNHAGEN, F. A. L'Origine Touranienne des Américains Tupis-Caribes et des Anciens Egyptiens. Indiquée principalement par la philologie comparée: traces d'une ancienne migration en Amérique, invasion du Brésil par les Tupis, etc., Vienne, Librairie I. et R. de Faesy \& Frick, 1876, p. XIV.

${ }^{6}$ Para Arno Wehling, atualmente o mais importante comentador do historiador, Varnhagen, seria "um historicista filosófico. Seu perfil e sua obra correspondem ao historicismo romântico-erudito". Porém, o próprio Varnhagen, ainda segundo Wehling, "como Martius, considerava-se adepto de uma história filosófica", WEHLING, A. op. cit., p. 44, 126-127. Para um Varnhagen próximo a Ranke ver GUIMARÃES, Lúcia M. Paschoal. Op. cit., p. 95 e MARTINIÈRE, Guy. Op. cit., 1991, p. 129. Para um Varnhagen mais próximo de uma tendência positivista ver SCHWARTZ, Stuart B. Op. cit., p. 192-193.

${ }^{7}$ ABREU, Capistrano de. Op. cit., 1878, p. 507.

${ }^{8}$ FREYRE, G. Casa grande e senzala. Rio de Janeiro: José Olympio, 5ํe․, no 107, p. 466.

${ }^{9}$ Ver KRIEGEL, Blandine. Les historiens et la monarchie. II. La défaite de l'érudition. Paris: PUF, 1998, e GRELL, Chantal. L'histoire entre érudition et philosophie. Étude sur la connaissance historique à l'âge des lumières. Paris: PUF, 1993. Para o caso brasileiro: GUIMARĀES, Manoel Salgado. Reinventando a tradição: sobre antiquariado e escrita da história. Humanas, Dossiê Historiografia e tradição clássica, Revista do IFCH/UFRGS, 2000, p. 111-143, sobretudo a parte dedicada às relações entre o IHGB e a Sociedade dos Antiquários do Norte da Dinamarca durante o século XIX.

${ }^{10}$ Arno Wehling também chega a uma conclusão parecida. Para ele, Varnhagen teria sido influenciado pela "cultura savante" da época, WEHLING, A. Op. cit., p. 136-137.

${ }^{11}$ VARNHAGEN, F. A. de. Historia das luctas com os Hollandezes no Brazil, desde 1624 a 1654. Vienna: Finsterback, 1871, p. XXV.

${ }^{12}$ ARENDT, Hannah. The concept of history. Between past and future. London: Faber and Faber, 1961, sobretudo p. 51-52.

${ }^{13} H G B$, II, 1, 1854, p. 12.

${ }^{14}$ ABREU, Capistrano de. Op. cit. 1882, p. 441.

${ }^{15}$ Sobre os jesuítas, ver $H G B$, II, 1, 1857, p. 197-198; sobre a inquisição, ver $H G B, \mathrm{I}, 1$, 1854, p. 87-88 e II, 1, 1857, p. 181-183.

${ }^{16}$ Carta ao Imperador, Madri, 14 de julho de 1857, CA, p. 245.

${ }^{17}$ Gonçalves de Magalhães, em polêmica com Varnhagen, levanta a questão da adesão do historiador às idéias do filósofo inglês, "Os indigenas do Brasil perante a historia", 
Revista do IHGB, 1860, p. 33. Anos antes, em 1849, Varnhagen escrevia que "ha hoje em dia uma tal praga de falsos philantropos, graças a Rousseau ou a Voltaire ou a nam sei quem, que a gente em materia d'indios quase nam pode piar, sem que lhe caiam em cima os franchinotes, com estas e aquellas sediças theorias pseudo-philantropicas", $\mathrm{Me-}$ morial Organico, Madri, D. Dominguez, 1849, p. 32-33.

18 Sobre a colaboração de Varnhagen no Panorama, ver MOREIRA, Thiers. "Varnhagen e a história da literatura portuguesa e brasileira”, Revista do IHGB, 1967, p. 155169. Acerca de Alexandre Herculano e o romantismo português CATROGA, Fernando. "Alexandre Herculano e o historicismo romântico", História da história de Portugal, séculos XIX-XX, Lisboa, Temas e Debates, 1998, p. 45-98.

19 BARTHES, R. "Aujourd'hui, Michelet", Le bruissement de la langue, Paris, Seuil, 1984, p. 244-245.

${ }^{20}$ Luiz Costa Lima procura remediar a ausência de reflexão sobre o assunto em seu livro: História. Ficção. Literatura, São Paulo, Companhia das Letras, 2006. Para uma análise mais específica da relação entre história e poesia em Aristóteles, ver BOULAY, Bérenger. "Histoire et narrativité. Autour des chapitres 9 e 23 de La Poétique d'Aristote", Lailes, Paris, 26, 2006, p. 171-187.

${ }^{21}$ As críticas desses autores ao estilo de Varnhagen encontram-se em: ABREU, Capistrano de., op. cit., 1878, p. 506, e op. cit., 1882, p. 441; VERISSIMO, José. História da literatura brasileira (1915), RJ, José Olympio, 1954, p. 193; ARARIPE, Tristão de Alencar."Indicações sobre a História Nacional", Revista do IHGB, 1894, p. 288-289; OLIVEIRA LIMA, Manuel. "Elogio de Francisco Adolfo de Varnhagen, Visconde de Porto Seguro (1903)”, Revista de Portugal, 222, 1964, p. 132-133.

22 "Aqueles que não são Michelet fazem como podem. Eles repartem entre si o trabalho", PÉGUY, Charles. "De la situation faite à l'histoire et à la sociologie dans les temps modernes”, Euvres en prose complètes, II, Paris, Gallimard, 1988, p. 498. À excessão da obra que Varnhagen publicou com José Conrado Carlos de Chelmicki, cujas seçôes são bem distintas (Varnhagen ocupa-se da parte histórica, enquanto Chelmicki da parte geográfica), não encontrei, por enquanto, nenhuma outra obra de Varnhagen em co-autoria. Ver VARNHAGEN, F. A. de./ CHELMICKI, J. C. C. de. Corografia Cabo-Verdiana, ou descripção geografico-histórica da provincia das Ilhas de Cabo-Verde e Guiné. Lisboa, Typ. de L. C. da Cunha, 1841. 2 vol.

${ }^{23}$ Oliveira Lima lembra em 1903, que quando jovem estudante de paleografia na Torre do Tombo, aluno do mestre José Basto (que fora um dos auxiliares de Alexandre Herculano na grandiosa Portugalio Monumenta Historica), tinha por hábito examinar minuciosamente velhos manuscritos em busca de documentos que, na sua "pretensão juvenil”, julgava capaz de desvendar alguns enigmas da história do Brasil. Foi com surpresa e desapontamento que em quase todos os papéis observou uma "marca" discreta, a lápis de um pesquisador que o precedera: Varnhagen. OLIVEIRA LIMA, M. op. cit., p. 124. Luis Camilo de Oliveira Neto, alguns anos mais tarde, também na Torre do Tombo, confirmou ter visto nos documentos que consultou o mesmo que Oliveira Lima: o $V$ de Varnhagen, apud LESSA, C. R. op. cit., 223, p. 106. Recentemente, em 2004, meu 
colega, o historiador Eduardo Neumann, relatou-me que pesquisando no arquivo de Simancas também encontrou documentos com a "marca" de Varnhagen.

${ }^{24} C A$, p. 103.

${ }^{25}$ BARBOSA, J. C. "Discurso", Revista do IHGB, 1839, p. 9-18. Procurei analisar este discurso em "Lição sobre a escrita da história. Historiografia e Nação no Brasil do século XIX”, Diálogos, Revista do Departamento de História da Universidade Estadual de Maringá, 2004, v. 8, n. 1, p. 11-29.

${ }^{26}$ SIMMONS, Jack. Southey. London, Collins, 1945, p. 173-174.

${ }^{27} H G B$, II, 1857, p. 343-344.

${ }^{28}$ VARNHAGEN, F. A. de. Examen de quelques points de l'histoire géographique du Brésil, Paris, L. Martinet, 1858, p. 7. Por sua vez, Southey reconhecia que apesar das qualidades de sua obra, ela era ainda incompleta. Ver History of Brazil, London, Longman, 1819, III, p. 879.

${ }^{29}$ Carta a Januário da Cunha Barbosa, 1839, CA, p. 40.

${ }^{30}$ VARNHAGEN, F. A. de. Les Hollandais au Brésil. Un mot de réponse à M. Netscher, Vienne, Éditions de l'Auteur, 1874, p. 8.

${ }^{31} H G B, \mathrm{I}, 1,1854$, p. 17-18.

${ }^{32} H G B, 3 / 4,1,1928$, p. 77.

${ }^{33} C A$, p. 370-371. Em 26 de junho de 1874, Varnhagen agradece ao imperador pelo título de Visconde, idem, p. 425. No entanto, em uma nota de sua História da Independência, publicada postumamente em 1916, Varnhagen comenta que durante o processo que culmina na independência política do Brasil, houve um personagem secundário, cuja alcunha era Porto Seguro: "A lembrança de haver estado este nome já associado a um tal esbirro não deixou de concorrer a esfriar um pouco a satisfação que tivemos ao receber um título associado aos nossos trabalhos históricos de toda a vida", "Historia da Independencia do Brasil”, Revista do IHGB, 1916, n. 31, p. 196.

${ }^{34}$ BN-RJ, mss. I-46, 13, 37.

${ }^{35}$ CA, p. 213.

${ }^{36}$ A nacionalidade de d. Maria Flávia de Sá Magalhães, mãe de Varnhagen, ainda não foi estabelecida com exatidão. Geralmente, acredita-se que ela nasceu em Portugal, ver $C A$, p. 91. A origem da suspeição vem, ao que parece, de uma resposta de José Ignacio de Abreu e Lima a uma dura crítica que Varnhagen endereçara-lhe. Abreu e Lima chamou Varnhagen de "filho de alemão e de uma senhora que não era brasileira". Varnhagen, no opúsculo onde refuta Abreu e Lima, dá a entender que sua mãe teria nascido em São Paulo, ver VARNHAGEN, F. A. de. Réplica apologetica de um escriptor calumniado e juizo final de um plagiario diffamador que se intitula general, Madrid, d. Dominguez, 1846, p. 5. Gilberto Freyre, no início dos anos 40 do século XX, faz um comentário, de passagem, que demonstra que ainda naquele período a identidade de d. Maria Flávia podia ser não-portuguesa: "É o caso de Varnhagen - filho de alemães - , que recebeu o título profundamente nacional de Barão de Porto Seguro", Novo Mundo nos trópicos, Obra escolhida, RJ, Nova Aguilar, 1977, p. 961. Para José Honório Rodrigues, Varnhagen era 
"filho de um alemão e de portuguesa", "Varnhagen, o primeiro mestre da historiografia brasileira (1816-1878)”. Revista de História da América, 88, 1979, p. 100.

${ }^{37}$ IGLÉSIAS, Francisco. Historiadores do Brasil. Rio de Janeiro: Nova Fronteira/EUFMG, 2000, p. 77-78.

${ }^{38}$ Trata-se do capítulo dedicado à análise do papel de seu pai na história brasileira intitulado: Minas de ferro. Varnhagen é o executor dos projectos d'elrei. $H G B$, II, 1, 1857, p. 357. Na segunda edição da História geral Varnhagen altera o título para: "Minas de ferro. Primeiras fundiçôes em Ponto Grande”. Procurei analisar a relação de Varnhagen, seu pai e José Bonifácio em: Em nome do pai, mas não do patriarca. Ensaio sobre os limites da imparcialidade na obra de Varnhagen. História, Unesp, 2005, 24/2, p. 207-240.

${ }^{39} H G B$, II, 1, 1857, p. 372.

${ }^{40}$ VARNHAGEN, F. A. de. Reflexões criticas sobre o escripto do seculo XVI impresso com o titulo de Noticias do Brazil. Collecção de Notas para a Historia e Geographia Ultramarinas, V, II, Lisboa, Typographie da Academia, 1839, 120 p. As "Reflexões" são os comentários de Varnhagen à obra de Gabriel Soares de Sousa, que ele não apenas editou, mas também atribuiu-lhe a autoria. Procurei tratar do assunto em: Quando um manuscrito torna-se fonte histórica: as marcas de verdade no relato de Gabriel Soares de Sousa (1587). Ensaio sobre uma operação historiográfica. História em Revista, Dossiê Historiografia, UFPel, 6, dez. 2000, p. 37-58.

${ }^{41}$ A maior parte das informaçôes dos últimos três parágrafos encontram-se na carta de Varnhagen a José de Sousa Soares de Andréa, de 16 de fevereiro de 1843, CA, p. 97-102.

42 Essa "narração ingenua e circunstanciada, feita a elrei" por uma "testemunha ocular", VARNHAGEN, F. A. de. Chronica do descubrimento do Brazil. O Panorama, 1840, p. 21. Ver SUSSEKIND, Flora. O Brasil não é longe daqui. São Paulo: Companhia das Letras, 1990, p. 19-20, p. 179.

${ }^{43}$ VARNHAGEN, F. A. de. Os Indios bravos e o Sr. Lisboa. Lima: Imprensa Liberal, 1867, p. 36-38. A crítica de J. F. Lisboa encontra-se em: Sobre a escravidão e a Historia geral do Brazil. Obras de João Francisco Lisboa, v. 3, 1866, nota C, p. 468-515.

${ }^{44} C A$, p. 235.

${ }^{45}$ CA, p. 101.

${ }^{46}$ VARNHAGEN, F. A. de. Op. cit., 1846, p. 7.

${ }^{47}$ No mesmo ano, o governo concede a Varnhagen o posto de $2^{\circ}$ tenente do Imperial Corpo de Engenheiros, abaixo portanto do posto que ocupava em Portugal. Ele sempre se ressentirá por essa nomeação. LESSA, C.R. Op. cit., 223, 1954, p. 134.

${ }^{48} C A$, p. 39-40.

${ }^{49}$ CA, p. 103-104.

${ }^{50}$ CORREA FILHO, Virgílio. Missões Brasileiras nos Arquivos Europeus. México: IPGH, 1952, p. 15 , no 5 .

${ }^{51}$ Esta "paixão pelo arquivo", segundo Anthony Grafton, ou o impacto causado pela documentação encontrada nos arquivos foi o que fez com que Ranke aparecesse co- 
mo o fundador de uma nova escola. GRAFTON, Anthony. Les origines tragiques de l'érudition. Une histoire de la note en bas de page. Paris: Éditions du Seuil, 1998, p. 3877 (sobretudo p. 40, et p. 48-57). Isto não implica, contudo, segundo Georg Iggers, que Ranke tenha sido o primeiro a aplicar um "novo" método crítico a essas fontes, ver IGGERS, Georg. The german conception of history. Middletown/Connecticut: Wesleyan University Press, 1969, p. 65-66. Peter Gay também ressalta a “obssessão" de Ranke pelos arquivos e a relação com suas viagens, GAY, Peter. Style in History. New York: Basic Books, 1974, sobretudo p. 70-71. Sobre a noção de "gosto pelo arquivo", ver FARGE, Arlette. Le goût de l'archive. Paris: Seuil,1989.

52 VARNHAGEN, F. A. de. O Caramurú perante a historia. Revista do IHGB, 1848, p. 129-152. Ver atas das sessōes de 3 de julho e 5 de agosto de 1847 na Revista do IHGB, 1847, respectivamente p. 410 e p. 431.

${ }^{53}$ VARNHAGEN, F. A. de. Florilegio da poesia brazileira. Lisboa: T. I-II, Imprensa Nacional, 1850. Entre os estudiosos da literatura ver VERÍSSIMO, José. Op. cit., p. 192193; COUTINHO, A. A tradição afortunada (o espírito de nacionalidade na crítica brasileira). Rio de Janeiro: José Olympio, 1968, p. 13; MARTINS, Wilson. A crítica literária no Brasil. São Paulo: Departamento de Cultura, 1952, p. 68-69. Antônio Cândido o insere na formação do cânon literário brasileiro, CÂNDIDO, A. Formação da literatura brasileira. Belo Horizonte: Itatiaia, 1981, 1, p. 350.

54 "O livro de Varnhagen - escreve Ferdinand Wolf em 1862 - intitulado Florilegio é ainda mais importante [do que aqueles que o precedem, como as obras de Januário da Cunha Barbosa, Joaquim Norberto de Souza e Silva e J. M. Pereira da Silva]. O sábio autor desta obra não se contentou de publicar pela primeira vez um grande número de trechos inéditos extraídos de fontes muito raras; ele demonstra sua origem alemã pela exatitude e a profundidade que nós vemos na introdução histórica colocada na abertura do primeiro volume. É essa última parte da obra que nos serviu de modelo para os quatro primeiros períodos", WOLF, Ferdinand. Le Brésil littéraire. Histoire de la littérature brésilienne suivie d'un choix de morceaux tirés des meilleurs auteurs brésiliens. Berlin: Asher \& Co., 1863, p. 4. ABREU, Capistrano de. Op. cit., 1878, p. 503.

55 VARNHAGEN, F. A. de. Memoria sobre os trabalhos que se podem consultar nas negociaçôes de limites do Império, com algumas lembranças para a demarcação destes. BN/RJ: mss. 21 folhas 7, 4, 87.

${ }^{56}$ GUIMARÃES, Manoel Salgado. Nação e civilização nos trópicos: o IHGB e o projeto de uma História Nacional. Estudos Históricos, Rio de Janeiro: 1988, p. 5-27.

${ }^{57}$ Também em 1851, Varnhagen apresentou um memorial ao governo em que pedia para ser agraciado com a condecoração do oficialato da Ordem Imperial do Cruzeiro. Eu não consegui verificar ainda se ele foi atendido. Parece-me que não. Lessa publicou a solicitação, $C A$, p. 166-169.

${ }^{58}$ ABREU, C. de. Op. cit., 1878, p. 505.

59 A despeito da enigmática carta que escreve a Joaquim Caetano Fernandes Pinheiro, então primeiro secretário do IHGB, em 22 de junho de 1859, na qual solicita que seu nome não seja proposto para sócio honorário: "Tenho motivos particulares para lhe pe- 
dir que não me proponha para honorário. As razões não são para agora. Um dia lh'as direi”, $C A$, p. 268. No entanto, na ata da sessão do dia 25 de maio de 1860 do IHGB, encontra-se um agradecimento de Varnhagen pelo título de "membro honorário". Revista do IHGB, 1860, p. 617.

${ }^{60}$ SOUZA, Pero Lopes de. Diário da navegação da Armada que foi à Terra do Brasil-em 1530. Lisboa: Typografia da Sociedade Propagadora dos Conhecimentos Uteis, 1839. Ver também a "Carta do Sr. Francisco Adolfo de Varnhagen à redacção, acerca da reimpressão do Diario de Pero Lopes, e que lhe servirá de prologo". Revista do IHGB, 1861, p. 3-8.

${ }^{61}$ CA, p. 280.

${ }^{62}$ LÉVI-STRAUSS, Claude. Tristes Tropiques. Paris: Plon, 1990, p. 103.

${ }^{63} C A$, p. 280.

${ }^{64}$ HARTOG, Fr. Le miroir d'Hérodote. Essai sur la représentation de l'autre. Paris: Gallimard, 1991, p. 272.

${ }^{65}$ VARNHAGEN, F. A. de. Op. cit.,1871, p. V-VI.

${ }^{66}$ CA, p. 286.

${ }^{67}$ VARNHAGEN, F. A. de. Succinta indicação de alguns manuscriptos importantes relativos ao Brazil e Portugal. Havana: Imprenta La Antilha, 1863. Ver também CA, p. 289-290.

${ }^{68}$ Varnhagen, F. A. de. Carta ao Excmo. Ministro da Agricultura, a respeito principalmente de vários melhoramentos nos engenhos d'assucar das Antilhas, applicaveis ao Brazil. Caracas: Espinal, 1863, p. 1-15.

${ }^{69}$ VARNHAGEN, F. A. de. La verdadera guanahani de Colon, Santiago, Imp. Nacional, 1864, p. X.

${ }^{70}$ VARNHAGEN, F. A. de. Amerígo Vespucci. Son caractère, ses écrits (même les moins authentiques), sa vie et ses navigations. Lima: Imp. du Lercurio, 1865, p. 29.

${ }^{71} C A$, p. 287.

72 Revista do IHGB, 1840, p. 105-108.

${ }^{73} \mathrm{Na}$ carta ao imperador citada como epígrafe a este artigo, de 1853, Varnhagen anuncia uma correção a Humboldt. Apesar disso, ele não hesitou em se servir da sua autoridade ao publicar um comentário elogioso do sábio à $H G B$, ver o post-scriptum, II, 1, 1857, p. 485. A mesma, digamos assim, metodologia de citar Humboldt, criticá-lo e depois usálo como referência encomiástica a sua própria obra encontra-se em Amerigo Vespucci, op. cit., nota 4. Alguns anos mais tarde, já em Viena, Varnhagen, naquela que se tornaria uma de suas últimas polêmicas, com Téofilo Braga, recorda a este que os sábios também cometem erros, e dá como exemplo Humboldt: "O homem mais sabedor e encyclopedico deste seculo, o grande Alexandre Humboldt não esteve fora do erro (e de muitos erros isento). Nos cinco volumes da sua profunda Historia Geographica do Novo Continente, a verdade, graças à sua boa fé, so vae aparecendo com o estudo e exame; e os volumes que successivamente se iam publicando contêm rectificações que às vezes destroem completamente asserções consignadas no anterior ou anteriores", Theophilo Braga e 
os antigos romanceiros de trovadores: (provarás para se juntarem ai processo). Vienna: Ed. por conta do autor, 1872 , p. 6-7.

${ }^{74}$ VIEIRA, Celso. Varnhagen. O homem e a obra. Rio de Janeiro: Editor Alvaro Pinto, 1923, p. 34.

${ }^{75}$ MAGALHÃES, Basilio de. Varnhagen. Revista da Academia Brasileira de Letras, 81, 1928, p. 108.

${ }^{76}$ LIMA, M. de O. Op. cit., p. 141.

${ }^{77} C A$, p. 301. Brito Broca chega mesmo a dizer, com exagero, que por este episódio Varnhagen pode ser considerado como um "precursor do panamericanismo", Românticos, pré-romanticos, ultra-românticos. Vida literária e romantismo brasileiro. São Paulo: Polis, 1979 , p. 195.

${ }^{78}$ MAGALHÃES, B. de. Op. cit., p. 108-109. Joaquim Nabuco contesta esta opinião, ver Um estadista do império. Rio de Janeiro: Nova Aguilar, 1975, p. 524.

${ }^{79}$ LIMA, M. de O. op. cit., p. 141.

${ }^{80} \mathrm{O}$ fato de o Chile ter apoiado o Paraguai, por exemplo, é explicado por Lessa como produto de interpretações "positivistas como aquela de Basilio de Magalhães", LESSA, C. R. Op. cit., 225, p. 152-154.

${ }^{81} C A$, p. 302. Ver também, CA, p. 304-305.

${ }^{82}$ D'AVEZAC, Armand. Sur l'histoire du Brésil. Examen critique d'une nouvelle Histoire Générale du Brésil. Bulletin de la Société de Géographie. Paris: Chez Arthus-Bertrand, agosto e setembro, 1857, p. 89-356. Ver a réplica de Varnhagen: Examen de quelques points de l'histoire géographique du Brésil, op. cit, 1858.

${ }^{83}$ Procurei reconstituir o debate, ainda que resumidamente, em: A geografia servia, antes de tudo, para unificar o império. Escrita da história e saber geográfico no Brasil oitocentista. Ágora, Unisc/RS, 11, 1, 2005, p. 79-99.

${ }^{84}$ CA, p. 298.

${ }^{85}$ CA, p. 308.

${ }^{86} C A$, p. 312-314.

${ }^{87}$ Heitor Lyra conta 37 cartas, porém na $C A$ de Varnhagen organizada por Clado Lessa, encontram-se entre 241 cartas, 67 endereçadas ao Imperador. LYRA, H. História de d. Pedro II. Fastígio (1870-1880), II, BH/SP, Itatiaia/Edusp, 1977, p. 117.

${ }^{88}$ No prefácio à primeira edição da $H G B$, Varnhagen declara-se: católico, monarquista (porém contrário ao absolutismo), justo e humano com os índios e defensor dos prestigíos honoríficos, II, 1, 1857, p. X. Essa declaração, no entanto, foi suprimida na segunda edição da obra.

${ }^{89}$ MONIZ, J. R. Recordações acêrca de Varnhagen. Apud, RODRIGUES, J. H. Op. cit., 1967, p. 173-174.

90 PORTO ALEGRE, M. A. Correspondência com Paulo Barbosa da Silva. ABL/RJ, 1990 , p. 60. 
${ }^{91}$ Major não apenas conhecia a obra de Varnhagen como o chama de "may valued friend", ver MAJOR, R. H. The life of prince Henry of Portugal, surnamed the navigator. London: A. Asher \& Co., 1868, p. 372-378. Ver também carta de Varnhagen ao Imperador, $1868, C A$, p. 323.

92 Varnhagen contestava, entre outras coisas, a afirmação de Major de que a "Vila do Infante", fundada por d. Henrique, estivesse situada no promontório de Sagres. Um documento contemporâneo, a carta de doação de 19 de setembro de 1460, mostrava, claramente, segundo Varnhagen, que a Vila se situava sobre a ponte chamada "Terça Nabal". Ele criticava ainda o fato de Major não ter tratado das concessões feitas pelos reis $\mathrm{d}$. Afonso e d. João II aos descobridores das novas terras, ver LESSA, C. R. Op. cit., 223, p. 238-239.

${ }^{3}$ VARNHAGEN, F. A. de. Noticia historica e decriptiva do mosteiro de Belem, Lisboa, Typographia da Sociedade Propagadora dos Conhecimentos Uteis, s/d.

${ }^{94} C A$, p. 328-330.

${ }^{95} C A$, p. 326-327. A carta de Varnhagen foi lida na sessão do IHGB de 25 de setembro de 1868, Revista do IHGB, 1868, p. 346-348.

${ }^{96} C A, 1869$, p. 334.

${ }^{97} C A, 1870$, p. 338-339. Em 1918, Capistrano de Abreu, aparentemente sem conhecer essa carta de Varnhagen, coloca em dúvida seu domínio do idioma alemão: “creio que, se algum dia soube a língua paterna, esqueceu-a depressa quase por completo. Se soubesse, e aproveitasse o livro de Guths-Muths, poderia ter antecipado a Wappaeus a muitos respeitos”, ABREU, Capistrano de. Correspondência. Rio de Janeiro, INL, II, p. 84. Encontrei pelo menos um texto atribuido a Varnhagen escrito em alemão. Trata-se do prefácio à obra do frei Luiz de Sousa, BN-RJ, 26,4,19D.

${ }^{98} C A$, p. 345-348.

${ }^{99}$ CA, p. 348-349.

${ }^{100} C A$, p. 358.

${ }^{101}$ Em uma carta datada de $1^{\circ}$ de março de 1873 a seu biógrafo, José Carlos Rodrigues, então editor da revista, $O$ novo mundo, publicada em Nova York, Varnhagen o previne através de um un post-scriptum: "Desculpe-me V. Sa se tomo a liberdade de lhe recommendar que esteja prevenido contra os juizos de Adolpho Coelho e Theophilo Braga contra Castilhos e outros amigos. São todos apaixonados e só pensam em fazer mal. Eu estive em Portugal, no anno passado e connheci todas estas miserias...”, CA, p. 395-396.

${ }^{102}$ Chegando um pouco antes do início do Congresso, Varnhagen aproveita a ocasiāo para visitar Moscou e ir a Nijni Novgorod. Para o relatório de Varnhagen sobre o Congresso ver: "Correspondência acerca do Congresso de estatistica reunido em São Petesburgo em 1872", CA, p. 372-380.

${ }^{103}$ Ver o relatório de Varnhagen para o governo brasileiro, $C A, 1873$, p. 401-405.

104 "Quelques renseignements statistiques sur le Brésil, tirés de sources officielles par le délégué au congrès de Budapesth, Vicomte de Porto-Seguro", Vienne, Imprimerie de la Cour Impériale et Royale, 1876, 23p., apud CA, p. 466 e p. 468-476. 
105 VARNHAGEN, F. A. de. Op. cit., 1876.

${ }^{106}$ VARNHAGEN, F. A. de. Op. cit., 1867, p. 36.

107 DENIS, Ferdinand. Quelques mots sur la deuxième édition de l'Historia geral du vicomte de Porto Seguro, ms. 3970, I, Biblioteca Sainte-Geneviève de Paris, (provavelmente de 1877), p. 224-225.

${ }^{108}$ ABREU, Capistrano de. Op. cit., 1878, p. 502.

${ }^{109} H G B$, III, 3/4, p. 373.

${ }^{110}$ Em 1849, Varnhagen defendia que a capital não podia estar localizada em um porto de mar, no entanto, não indica um lugar específico, somente afirma que ela deva ser transferida para o interior, ver VARNHAGEN, F. A. Op. cit., 1849, p. 3-6.

${ }^{111}$ VARNHAGEN, F. A. de. A questão da capital: maritima ou no interior? Vienna, Carlos Gerold, Edição por conta do Autor, 1877, p. 1.

112 Idem, p. 12 (grifos T.C.).

${ }^{113}$ Idem, p. 12-13.

${ }^{114} C A, 1877$, p. $487-490$.

${ }^{115}$ FOUCAULT, Michel. Naissance de la clinique. Paris: PUF, 1963, p. IX.

${ }^{116}$ Varnhagen comunica suas conclusōes sobre Cabral ao IHGB, ver "Nota acerca de como não foi na coroa Vermelha, na enseada de Santa Cruz, que Cabral primeiro desembarcou, e em que fez dizer a primeira missa”, Revista do IHGB, 1877, p. 5-37. Suas afirmações foram fortemente contestadas. Para o comentário sobre o provável diário ver VARNHAGEN, F. A. de. A questão da capital: maritima ou no interior. Op. cit., p. 13.

${ }^{117}$ Seu filho, Xavier de Porto Seguro confirma, em suas memórias, que a viagem foi a causa de sua morte: "no fim de nosso segundo ano de colégio, meu pai teve a infeliz idéia de fazer uma viagem ao Brasil. Essa viagem foi a causa de sua morte. Ele ficou seis meses ausente, e voltou com uma doença nos pulmões", PORTO-SEGURO, Xavier de. Mémoires, recueillies et mises en ordre par Hippolyte Buffenoir. Paris: Bureaux de la Revue de la France Moderne, 1896, p. 21.

${ }^{118}$ Citado em GARCIA, Rodolfo. Ensaio bio-bibliographico sobre Francisco Adolpho de Varnhagen, Visconde de Porto Seguro. Apud HGB, II, 3/4, 1928, p. 452.

${ }^{119}$ VERÍSSIMO, José. Op. cit., p. 191.

${ }^{120}$ Varnhagen deixou a esposa e dois filhos, Xavier e Luis. O primeiro, nascido em Lima, morre em 1894, aos 29 anos. Sua mãe publicou suas memórias, escritas originalmente em francês, em 1896. Luis, nasceu em Viena, e adotou a nacionalidade materna, e como o pai tornou-se diplomata, porém do governo chileno. Seu último posto foi o de Ministro Plenipotenciário em Berlim. Morreu no Rio de Janeiro em 1939. Os filhos de Varnhagen não tiveram descendentes. Os Porto-Seguro, antes da metade do século XX, não existiam mais. Ver PORTO SEGURO, Xavier, op.cit.; e LESSA, C. R. op. cit., 223, p. 296-297. Sobre a relação de Varnhagen com sua família é possível se ter alguma idéia a partir da sua correspondência e do pequeno livro de seu filho Xavier Porto-Seguro. No 
que se refere à perspectiva desse texto, no entanto, nota-se que não era raro Varnhagen deixar a família pelo trabalho intelectual. Ver, por exemplo, $C A$, p. 463 e p. 478-479.

${ }^{121}$ Carta a d. Pedro II, 1854, CA, p. 213.

122 "Trata-se de aquisição para sempre, mais que de uma peça para um concurso", Prefácio à História da guerra do Peloponeso, apud HARTOG, F. A história de Homero a Santo Agostinho. BH: EUFMG, 2001, 22, (1), p. 81.

${ }^{123}$ BOURDIEU, Pierre. L'illusion biographique. Actes de la Recherche en Sciences de Sociales, $\mathrm{n}^{\mathrm{os}} 62 / 63,1986$, p. 69-72.

${ }^{124}$ MACEDO, J. M. Revista do IHGB, 1878, p. 489.

${ }^{125}$ MAGALHĀES, B. de. Op. cit., p. 95; LESSA, C. R. Op. cit., 223, p. 293-294.

126 "Critica”, apud MENEZES, R. Dicionário literário Brasileiro. São Paulo: Saraiva, 1969 , p. 1289.

${ }^{127}$ ABREU, C. de. Op. cit., 1878, p. 505.

${ }^{128}$ BELLIDO, Remígio de. Varnhagen e a sua obra. Comemoração do centenário. São Paulo: Rothschild, 1916.

${ }^{129}$ FLEIUSS, Max. Recordando (casos e perfis), III, Rio de Janeiro: IBGE, 1943, p. 106-107.

${ }^{130}$ Este distanciamento não foi suficiente para impedir que, de certa forma, o "povo", que ironia, por circunstâncias que ainda desconheço, o tenha homenageado por meio da escola de samba Mocidade Independente de Padre Miguel, que, com o samba-enredo "Vida e obra de Francisco Adolfo de Varnhagen", ficou em 7o lugar no carnaval carioca de 1969. José Honório Rodrigues menciona o episódio, op. cit., 1979, p. 121. Agradeço ao meu bolsista de IC, Evandro Santos, o detalhe sobre a colocação da escola.

${ }^{131}$ Ver sítio: http://www.sorocaba.com.br/fotos/monumentos.

${ }^{132}$ ABREU, Capistrano de. Op. cit., 1882, p. 439.

${ }^{133}$ No sentido que Paul Ricœur concede aos termos: "O começo é histórico, a origem é mítica”, La mémoire, l'histoire, l'oubli. Paris: Seuil, 2000, p. 174.

${ }^{134}$ Varnhagen, 'Heródoto do Brasil'. REIS, J. C. Op. cit., 1997, p. 106-107.

135 Para o caso de Heródoto, ver: MOMIGLIANO, A. The place of Herodotus in the history of historiography. Secondo Contributo. Roma: 1960, p. 29-44 (sobretudo as páginas iniciais); HARTOG, F. Op. cit., 1991, p. 12, p. 313-316, p. 379-380.

${ }^{136}$ Segundo Arnaldo Momigliano, Heródoto foi, entre os autores da Antiguidade, aquele que mais viajou, o que lhe confere também o título de pai da etnografia. MOMIGLIANO, A. Les fondations du savoir historique. Paris: Les Belles Lettres, 1992, p. 5859, ver também HARTOG, François., op. cit., 1991, p. 379.

137 Sobre a recepção de Tucídides pela historiografia oitocentista ver HARTOG, François. L'œil de Thucydide et l'histoire 'véritable', Évidence de l'histoire. Ce que voient les historiens, Paris: EHESS, 2005, p. 82. Até o momento desconheço o motivo que levou Varnhagen a não publicar a História da independência. A hipótese mais comum é que ele não teve tempo. Pode ser. Desconfio, todavia, que não seja apenas essa a razão. Tal- 
vez fizesse parte dessa precaução, desse cuidado de si que mencionei acima, afinal, escrever sobre pessoas muito próximas poderia causar embaraços desnecessários. Ver $C A$, p. 432, p. 440 e p. 467 e também o prefácio à Historia da Independência e LESSA, C. Op. cit., 224, p. 150 .

${ }^{138}$ VARNHAGEN, F. A. de. Historia das luctas com os Hollandezes. Op. cit., 1871, p. XXIX.

${ }^{139}$ MICHELET, J. Préface (1869). Histoire de France. Euvres complètes. Paris: Flammarion, 1974, p. 11-14.

140 "E é verdade ainda que, brasileiro, escrevendo uma história da civilização do Brasil pelos portugueses, quer dizer pelos ancestrais da maior parte dos cidadãos brasileiros atuais, eu não poderia jamais colocar-me sob o ponto de vista francês, nem holandês, nem inglês, nem espanhol. Pela mesma razão, eu também não poderia colocar-me sob o ponto de vista negro ou indígena”, VARNHAGEN, F. A. de. Op. cit., 1858, p. 53-54.

141 "O fato de ser um vencido constitui uma experiência histórica específica e original que não se aprende, nem se troca, e que permite a elaboração de um método capaz de conferir a um ganho de experiência uma existência durável", "Mutation de l'expérience et changement de méthode. Esquisse historique-anthropologique", KOSELLECK, Reinhart. L'expérience de l'histoire. Paris: Hautes Études/Gallimard/Le Seuil, 1997, p. 241. ${ }^{142}$ Idem, p. 239.

\section{Referências bibliográficas}

\section{Obras de Varnhagen}

VARNHAGEN, F.A. de.; CHELMICKI, J.C.C. de. Corografia Cabo-Verdiana, ou descripção geografico-histórica da provincia das Ilhas de Cabo-Verde e Guiné. Lisboa: Typ. de L.C. da Cunha, 1841.

VARNHAGEN, F.A. de. Correspondência ativa. Org. por C.R. Lessa. Rio de Janeiro: INL/MEC, 1961.

. Reflexões criticas sobre o escripto do seculo XVI impresso com o titulo de Noticias do Brazil. Collecção de Notas para a Historia e Geographia Ultramarinas, V, II. Lisboa: Typographie da Academia, 1839.

. Réplica apologetica de um escriptor calumniado e juizo final de um plagiario diffamador que se intitula general. Madrid: D. Dominguez, 1846.

. O Caramurú perante a historia. Revista do IHGB, 1848, p. 129152. . Florilegio da poesia brazileira. Lisboa: Imprensa Nacional, 1850. . Historia geral do Brazil. Madrid: Imprensa da V. de Dominguez,

$1854-1857$. 
ris: L. Martinet, 1858.

Examen de quelques points de l'histoire géographique du Brésil. Pa-

- Carta do Sr. Francisco Adolfo de Varnhagen à redacção, acerca da reimpressão do Diario de Pero Lopes, e que lhe servirá de prologo. Revista do $I H G B, 1861$, p. 3-8.

. Succinta indicação de alguns manuscriptos importantes relativos ao Brazil e Portugal. Havana: Imprenta La Antilha, 1863.

. Carta ao Excmo. Ministro da Agricultura, a respeito principalmente de vários melhoramentos nos engenhos d'assucar das Antilhas, applicaveis ao Brazil. Caracas: Espinal, 1863. p. 1-15.

. La verdadera guanahani de Colon. Santiago: Imp. Nacional, 1864.

. Amerígo Vespucci. Son caractère, ses écrits (même les moins authentiques), sa vie et ses navigations. Lima: Imp. du Lercurio, 1865.

. Os Indios bravos e o Sr. Lisboa. Lima: Imprensa Liberal, 1867.

. Theophilo Braga e os antigos romanceiros de trovadores: (provarás para se juntarem ai processo). Vienna: Ed. por conta do autor, 1872.

. Les Hollandais au Brésil. Un mot de réponse à $M$. Netscher. Vienne: Éditions de l'Auteur, 1874.

- Quelques renseignements statistiques sur le Brésil, tirés de sources officielles par le délégué au congrès de Budapesth, Vicomte de Porto-Seguro. Vienne: Imprimerie de la Cour Impériale et Royale, 1876.

. L'Origine Touranienne des Américains Tupis-Caribes et des Anciens Egyptiens. Indiquée principalement par la philologie comparée: traces d'une ancienne migration en Amérique, invasion du Brésil par les Tupis etc. Vienne: Librairie I. et R. de Faesy \& Frick, 1876.

. A questão da capital: maritima ou no interior? Vienna: Carlos Gerold, edição por conta do autor, 1877.

. Memoria sobre os trabalhos que se podem consultar nas negociações de limites do Império, com algumas lembranças para a demarcação destes. BN-RJ, mss. 21 folhas $7,4,87$.

. Noticia historica e decriptiva do mosteiro de Belem. Lisboa: Typographia da Sociedade Propagadora dos Conhecimentos Uteis, s/d.

. Historia da independencia do Brasil. Revista do IHGB, 1916, p.

$5-598$.

. História geral do Brasil (1877). 3a4aa edição. São Paulo: Melhoramentos, 1928. 


\section{RESUMO}

O objetivo deste artigo é o de esboçar uma breve antologia da vida e obra do historiador Francisco Adolfo de Varnhagen (1816-1878), cuja existência transcorre praticamente toda fora do Brasil. Procuro relacionar parte da sua imensa obra a esse olhar distanciado, efeito de seu movimento quase ininterrupto em busca de arquivos e documentos sobre a história e a geografia do Brasil que se encontravam no exterior. Além disso, tento enfatizar a importancia da viagem e da visão in locu como recursos cognitivos para a escrita da história em um contexto marcado pela emergência da história como ciência e sua ambição à objetividade narrativa e à imparcialidade do historiador.

Palavras-chave: Varnhagen, historiografia, escrita da História.

\section{ABSTRACT}

The purpose of this article is to outline a life and work brief anthology of historian Francisco Adolfo de Varnhagen (1816-1878), who lived mainly out of Brazil. I try to relate part of his extensive work to a distant look, as an effect of his continuous movement in search of files and documents on Brazil's history and geography which were found abroad. In addition, $i$ intend to emphasize the relevance of journeys and in locu wiews as cognitive resources for writing history in a context characterized by the emergence of history as a science and its claim for narrative objectivity and for historians impartiality.

Keywords: Varnhagen, historiography, History writing.

Recebido em março de 2007 e aprovado em agosto de 2007 